\title{
Human Geography, Cartography, and Statistics: A Toolkit for Geopolitical Goals in Hungary until World War II
}

\section{Ferenc Gyuris}

\begin{abstract}
After World War I, which resulted in Hungary surrendering approximately twothirds of its territory, strong support was given to "Hungarian Studies" aimed at strengthening Hungarian identity and justifying revisionary attempts. This paper investigates how geography in general, and statistical and mapping methods in human geography in particular, contributed to the revisionist project in interwar Hungary. To put the story in its disciplinary context, the paper begins by presenting the links between power, territorial politics, and geography that have existed in Europe since geography was institutionalized as academic discipline. Second, the paper investigates how geography and political power became intertwined in Hungary in the decades between 1867 and the end of the peace negotiations after World War I. Third, the main section of the paper employs some case studies to explain how human geographers in Hungary deployed some of their central arguments during the interwar period to delegitimize the post-WWI European order and to substantiate the righteousness of Hungarian revisionist goals. Claiming that the new truncated borders of Hungary ran counter to "scientific necessity," interwar geographers presented arguments that were intended to strengthen claims of the nation's physical and economic unity, and to highlight the so-called historical stability of Greater Hungary, a stability that had proved crucial, they argued, to the spread of European civilization. The paper concludes by comparing these arguments with their counterparts in neighboring countries to reveal how a "toolkit" of prefabricated geographical arguments, prevailing not only in Hungary but in international geography at the time, was utilized in various countries to justify what were clearly antagonistic political goals.
\end{abstract}

Keywords: Geography in Hungary, Knowledge and Power, Territorial Revision, Thematic Maps, War and Science

Biography: Ferenc Gyuris is Assistant Professor of Geography at the Department of Regional Science at Eötvös Loránd University, Budapest (Hungary), where he teaches courses on concepts in human geography, spatial disparities, and thematic mapping. He earned his PhD in Geography at Heidelberg University (Germany) in 2012. His book The Political Discourse of Spatial Disparities: Geographical Inequalities Between Science and Propaganda was published by Springer in 2014. His current research interests include the production and utilization of scientific knowledge, the link between science and propaganda, and the geographies of Communism and post-Communist transition. He has written several papers, published in English, Hungarian, Chinese, German, and Russian, on topics related to these fields. 
Gyuris, Ferenc. "Human Geography, Cartography, and Statistics: A Toolkit for Geopolitical Goals in Hungary until World War II." Hungarian Cultural Studies. e-Journal of the American Hungarian Educators Association, Volume 7 (2014): http://ahea.pitt.edu DOI: 10.5195/ahea.2014.173

The peace negotiations following the devastating conflict of World War I resulted in the redrawing of the political geography of Europe. Especially remarkable were changes in the areas once belonging to the Austro-Hungarian Monarchy. The empire, which was at once one of the most ethnographically diverse but least powerful empires in prewar Europe, fell apart in 1918. Austria and Hungary, its two components with a relatively equal level of political sovereignty since 1867, suffered enormous territorial losses. Due to the 1920 Treaty of Trianon, Hungary surrendered approximately two-thirds of its area and population, and roughly one-third of ethnic Hungarian population (Hajdú 1998: 21). These casualties traumatized broad strata of Hungarian society as well as the Hungarian elite (see Jobbitt 2011). Hence, the new nationalist-conservative regime emerging in 1920 under the leadership of Miklós Horthy, a former naval aide-de-camp of the Habsburg Emperor Franz Joseph I who served as the Regent of Hungary between 1920 and 1944 , defined territorial revision as its main goal in foreign politics. In line with this, strong support was given to disciplines whose capacity seemed especially suited to strengthening Hungarian identity, justifying revisionary goals, and providing useful information to decisionmakers in the case of new territorial negotiations in the future. The circle of such magyarságtudományok ['Hungarian studies'] included geography, together with ethnography, history, and statistics (Györi and Gyuris 2012: 111; Keményfi 2006: 420).

The main aim of this paper is to reveal how geography in general, and statistical and mapping methods in human geography in particular, contributed to the revisionist project in interwar Hungary. In my view, explaining this issue is hardly possible without presenting how the discipline became intertwined with political power, and how thematic maps and the extensive use of statistics came to play an important role in this process at both the international and national levels. Therefore, the essay is split into three parts. First, I present the links between power, territorial politics, and geography that have existed in Europe since geography was institutionalized as an academic discipline. Here I put special emphasis on World War I and the peace negotiations which followed, and the widespread utilization of maps. This overview reveals both the real and claimed capabilities of geographers, and provides insight into the expectations that were placed on human geography during the war and at the succeeding peace talks. Second, I investigate how geography intersected with political power in Hungary in the decades between 1867 and the end of peace negotiations after World War I. This section examines and reveals the basis upon which interwar Hungarian geography was constructed, and the forces that influenced it. Third, in the main section of the paper, I use case studies to examine the main arguments that human geography produced in Hungary in the interwar period to delegitimize the post-WWI European order, and to substantiate the righteousness of Hungarian revisionist goals.

\section{Geography and Power: A Brief History of a Mutually Fruitful Cooperation}

Although scientists are often assumed to work in an "ivory tower," science itself does not "happen" in a sealed container independent from the world "out there." Scientific activities and knowledge production in general always take place within a certain social, economic, and political context, a reality which brings science and scientists into a host of mutual relationships with all forms of power. Political, economic, and military power relies on the analytical abilities of science to identify potential solutions to the problems it has to cope with, and is dependent upon the potential of scientists to create knowledge that justifies the ruling order. Science, too, is reliant upon power, whose permanent support guarantees not only adequate material and institutional accommodations for research, but also a relatively high level of social prestige for 
Gyuris, Ferenc. "Human Geography, Cartography, and Statistics: A Toolkit for Geopolitical Goals in Hungary until World War II." Hungarian Cultural Studies. e-Journal of the American Hungarian Educators Association, Volume 7 (2014): http://ahea.pitt.edu DOI: 10.5195/ahea.2014.173

scientists themselves (Konrád and Szelényi 1979; Meusburger 2005). Due to these mutual interests, in each society power tends to provide some surplus resources (material as well as symbolic) to "cooperative" scientists. Likewise, most scientists usually tend to become "useful"; that is, they remain both competent in solving the problems and addressing the challenges that power faces, while simultaneously remaining ideologically compatible with the regime in question.

Those who have been involved in the production of what is nowadays considered geographical knowledge have been no exception to this general phenomenon outlined above. As early as ancient times, discoverers, travelers, and merchants who provided new information about remote lands, and astronomers who calculated more exact coordinates of geographical locations, often gained high reputations and firm support if their knowledge helped either to identify new trade opportunities, or to defend their own land or to conquer other ones, or to justify the ruling order and keep society under control. The case was similar for many writers and mapmakers, who transformed geographical data into easily interpretable forms. The value of these and other related activities increased remarkably due to both the "Age of Reconnaissance" (Parry 1982) and the Enlightenment, with science usurping the church as the legitimate authority of the "truth." Later still, as a handmaiden of the intensifying race between the European powers to divide up the Earth, geography became "unquestionably the queen of all imperial sciences" (Richards 1993: 13). The discipline, in fact, proved most efficient in fabricating forceful arguments for colonization. These arguments claimed that the "lack of civilization" in remote continents had been determined by environmental conditions (Livingstone 2002: 2011), and thus could not be cured without European intervention, therefore presenting the process of colonization as a mission civilisatrice ['civilizing mission'] (van der Velde 1995: 81, 84).

Geography, together with history, was also considered the most efficient medium of disseminating both the territorial aspirations of the state and national identity (for the French case see Heffernan 2001: 35). This fixation with imperialism and nationalism led both to a mushrooming of geographical societies (beginning with the Société de Géographie de Paris ['Paris Geographical Society'] (SGP) in 1821, the Gesellschaft für Erdkunde zu Berlin ['Berlin Society for Geoscience'] in 1828, and the Royal Geographical Society (RGS) in London in 1830) (Heffernan 2009: 7-8), as well as to the growth of university departments of geography, the increasing inclusion of geographical science in public school curricula (Heffernan 2009: 1012), and firm links between geography, mapmaking, and intelligence (Heffernan 1996, Krasznai 2003, 349).

\section{Geography and Expansionary Goals: Experiences From the "Great War"}

The outbreak of World War I in 1914 gave even stronger impetus to geography (see also Hajdú in this issue). One reason was the need for sophisticated and reliable topographic information in warfare. Perhaps ironically, the contribution of cartography to the military was less significant than one might think. For example, contrary to expectations even at the time, the military importance of the ninety new 1:1 million map sheets the RGS produced in Britain about Europe and its broad surroundings "was minimal" (Heffernan 2000: 323). This is not to say, however, that the activity of the RGS was insignificant or unimportant in other respects. In fact, the work of the London-based society proved remarkably useful to political power. On the one hand, the RGS created and disseminated a huge amount of propagandistic material to justify British war efforts. On the other, it gathered a huge set of information the British delegation could later draw upon in postwar peace negotiations to justify its geopolitical interests (323). 
Gyuris, Ferenc. "Human Geography, Cartography, and Statistics: A Toolkit for Geopolitical Goals in Hungary until World War II." Hungarian Cultural Studies. e-Journal of the American Hungarian Educators Association, Volume 7 (2014): http://ahea.pitt.edu DOI: 10.5195/ahea.2014.173

Likewise in France, the main goals of geographical science included educating French citizens about the territorial claims of the state, producing material to be used in campaigns to influence the political opinions of intellectuals in neutral countries (including the United States), and preparing briefs for the peace negotiations at the end of the war (325-327). In the USA, which had formerly been reluctant to get involved in European politics, geography was fueled by the desire to produce "neutral" knowledge with "scientific credibility" so that the United States "as an honest, disinterested and objective arbitrator between rival European powers" could contribute to elaborating "perfectly rational solutions" to the "Old World's" political tensions (327-330). In the light of these, it is hardly surprising that most countries sent numerous geographical experts to the peace negotiations (Krasznai 2003: 348-349). Furthermore, the territorial changes resulting from the peace treaties underscored the crucial importance of geography for the national elites. The winners were convinced about the role of their geographers in the successful outcome of the war, while the losers now regarded full support of geographical research to be crucial, and lamented its neglect prior to the war. Therefore, the number of geography departments and the size of their staff further increased throughout Europe, with geographical knowledge becoming a cornerstone of primary and secondary education programs as well (Heffernan 2009: 14-15).

As part of geography's resurgence after the war, cartography (especially thematic cartography) and the extensive use of statistics played a much more important role than ever before. During the war as well as at the peace negotiations that followed, the number of maps the geographers of a particular nation had already produced, and the statistics they had gathered, provided an image of superiority and, hence, a certain legitimate authority to these researchers, their nation, and their political leaders as well. It is no wonder, then, as Heffernan (2000: 323) underscores, that for the RGS it was an explicit objective during the war "to ensure that the new political boundaries of Europe and the Middle East would be shown to an expectant world on a British map designed and produced by British geographers in London" (my emphasis). It is important to note that topographic maps that accurately indicated the geographical position of certain locations were not the only "useful" maps produced during and immediately after the war. Thematic maps revealing the spatial distribution of social, economic, and political phenomena through sophisticated methods of visualization proved in many cases even more valuable. A remarkable example of this was a series of political maps that the African explorer and colonial administrator Sir Harry Johnston presented during his 1915 lecture to the RGS. The maps depicted the political geography of Africa at the beginning of the war, as well as a possible outcome for 1916 if Germany had won the war by then, and also an Africa in which Germany had been deprived of its colonies as a consequence of a future British and French victory. As Heffernan (2002) points out, Johnston was actually "ill-informed" (217) about German ambitions, and thus the accuracy of his maps were "highly debatable" (216). Still, his cartographic images soon found their way to a broad public, and proved highly effective in making the public aware of the crucial importance of war efforts, not only in Britain, but in other countries as well, including then neutral ones. For this reason, on May 5, 1915 The Globe in Toronto judged the material "the most important unofficial document that has crossed the Atlantic since the beginning of the war" (cited in Heffernan 2002: 216).

The success of thematic maps was partly linked to the fact that this sort of cartography could rely on a huge number of base maps and on improved technology that enabled even nonscientists to create maps. Whereas throughout much of the nineteenth century a high level of technical expertise and statistical know-how had been required to illustrate hidden spatial 
Gyuris, Ferenc. "Human Geography, Cartography, and Statistics: A Toolkit for Geopolitical Goals in Hungary until World War II." Hungarian Cultural Studies. e-Journal of the American Hungarian Educators Association, Volume 7 (2014): http://ahea.pitt.edu DOI: 10.5195/ahea.2014.173

interrelations (Godlewska and Grek Martin 2009: 361), by the beginning of the twentieth century, access to new technologies and sources of information became the basis for the creation and dissemination of a wide variety of thematic maps. Moreover, in comparison to analytical texts in scientific textbooks and articles, thematic maps as images could mediate a huge amount of multifaceted information in a visual language, which made much more sense for non-scientists (be they politicians at the peace negotiations or soldiers on the front) and could make a strong propagandistic impression on the viewer, even in a few seconds (see Meusburger, Heffernan, and Wunder 2011: 4-7). In turn, by exploiting the legitimate authority of science, and by depicting statistical data expressed in numbers, thematic maps automatically suggested mathematical rigor and the "objective" representation of the world.

\section{Geography and Power: The Hungarian Story}

Hungary was a subordinate part of the Habsburg Empire until the Austro-Hungarian Compromise of 1867, and so the emergence of a national Hungarian geography only became possible after this date. The institutionalization of the discipline took root quickly, however. At the University of Pest, a geography department was established as early as 1870, with János Hunfalvy, whose scientific activity mainly embraced history, statistics, and geography, as chair. This was the fourth such institution in the world, and resembled similar departments in Berlin, Göttingen, and Paris (Fodor 2006: 128). (Pest was one of the three cities that, after a decision made in 1872, was merged into Budapest, a new, more grandiose capital city expected to compete with Vienna. In 1872, the university was renamed to University of Budapest.) The same year, the Magyar Földrajzi Társaság ['Hungarian Geographical Society'] (MFT) was formed independently from the Österreichische Geographische Gesellschaft ['Austrian Geographical Society'] (ÖGG), which had been established in Vienna in 1856. One year later, the MFT launched its journal Földrajzi Közlemények ['Geographical Review']. In 1874, a second geography department was organized at the University of Kolozsvár (now Cluj-Napoca in Romania) (131), followed by the University of Debrecen in 1914 (212) and the University of Pozsony (now Bratislava in Slovakia) in 1918 (213).

In accordance with international trends, geography in Hungary paid much attention to remote lands. In 1877, the MFT launched a three-year-expedition to Central, East, and South Asia (672-673), and between 1887-89 another one was organized to the region of East Africa that today belongs to Kenya and Tanzania (770). These projects were driven both by a considerable demand from the public for adventurous stories (which dominated Földrajzi Közlemények in the first period) (144) and by geopolitical interests. One of the motivations for the 1887-89 expedition was, in fact, to assess the possibility for the establishment of a small Hungarian colony in Africa (132), a goal that ultimately remained unfulfilled. Later on, especially in the 1900s and 1910s, science as well as politics and economics showed an increasing interest towards the Balkans, which was regarded as a potential zone for the expansion of Hungary's sphere of influence. Geography became heavily involved in this initiative by contributing research and through publication activities (Hajdú 2007: 16-24, Köszegi 2011: 12-16). The creation of the Magyar Adria Egyesület ['Hungarian Adriatic Association'] in 1910, and the introduction of its journal A Tenger ['The Sea'] in 1911-a project that was born out of a scientific collaboration with several geographers involvedunderlined similar geopolitical as well as scientific interests. 
Gyuris, Ferenc. "Human Geography, Cartography, and Statistics: A Toolkit for Geopolitical Goals in Hungary until World War II." Hungarian Cultural Studies. e-Journal of the American Hungarian Educators Association, Volume 7 (2014): http://ahea.pitt.edu DOI: 10.5195/ahea.2014.173

Domestic research topics attracted less attention from Hungarian geographers at the time, so much so that there was a distinct lack of in-depth scientific studies focusing on the peripheral regions of the country, including the Carpathian Mountains, whose national belonging only later became a major matter of debate during World War I and at the post-WWI peace negotiations. Even works on Hungary produced in foreign languages were scarce. Hungarian geographers also fell short of their counterparts in neighboring countries in their failure to efficiently mobilizing international networks of political supporters among intellectuals of the Triple Entente. At postwar peace negotiations the chief geographer of the South-Slavic delegation, for example, was the Serbian Jovan Cvijič, who gave lectures at the Sorbonne in Paris during the war as a visiting professor, and who had an international reputation for his studies in the Balkans (Krasznai 2003: 349). In the meantime, the secretary of the French peace preparations agency, the Comité d'études, was the geographer Emmanuel de Martonne (Heffernan 2000: 327), a firm supporter of Romanian territorial claims who was highly acknowledged for his extensive studies in Romania since the early 1900s (Krasznai 2003: 350-353).

In 1918, in the light of the country losing the war, Hungarian geographers made desperate attempts to make up this disadvantage. Five professors of the University of Pozsony under the lead of the young geographer Gyula Prinz, for instance, formulated an appeal to educated foreigners - one they entitled Pro Hungaria ['For Hungary'] — in order to make arguments for sustaining Hungary's borders. This was soon followed by the manifesto of the Hungarian Geographical Society (Magyar Földrajzi Társaság) in 1918, one that was driven by similar motivations, and that contained similar content (Hajdú 2000). Furthermore, Count Pál Teleki, Chief Secretary of the Hungarian Geographical Society since 1911 (Fodor 2006: 760), and a descendant of one of the most influential noble families in Hungary, suggested in October 1918 that a peace preparation committee should be established. As its first goal, this committee was charged with compiling an ethnographic map of Hungary as accurate as possible so that it could be presented to the representatives of foreign powers during the negotiations.

The project evolved quite slowly in the coming turbulent months. On November 11, the Austro-Hungarian Empire was dissolved. This soon put an end to the monarchy in Hungary as well. On November 16, the Hungarian Democratic Republic was proclaimed, which was in March also overturned by a revolution, opening the door for the creation of the Hungarian Soviet Republic. After the latter collapsed, the Kingdom of Hungary was restored, now as an independent state. The work launched by Teleki resulted in the official establishment of the Béke-elökészitö Iroda ['Peace Preparation Bureau'] in August 1919. But again the preparation of materials proceeded slowly due to the Romanian army occupying Budapest and most areas eastwards between August and November 1919. Despite these hardships and setbacks, maps with their statistical appendices were nevertheless prepared and printed, including translations into French and English, by the end of the year (Romsics 2007: 117-118). The position of geography for Hungary at the peace negotiations was secured by Pál Teleki, who was one of the Hungarian chief delegates sent to France in January 1920 (119-120). The arguments made by the Hungarian delegation and the materials it presented were to a large extent geographical in nature. Yet, they had almost no effect on the outcome of the peace conference, largely because the new national boundaries had crystallized during discussions held between the victorious powers as early as January 1919, and had even been approved by the main organs of the peace conference during May and June 1919, well before the Hungarian delegation arrived (Romsics 2010: 142). 
Gyuris, Ferenc. "Human Geography, Cartography, and Statistics: A Toolkit for Geopolitical Goals in Hungary until World War II." Hungarian Cultural Studies. e-Journal of the American Hungarian Educators Association, Volume 7 (2014): http://ahea.pitt.edu DOI: 10.5195/ahea.2014.173

In fact, the delegation soon realized that an unwanted outcome was unavoidable. In the light of this, Hungarian delegates began to consider their activity at the peace conference as preparation for the irredentist struggle that lay ahead, and the negligence of the victorious powers as justification for a revisionist postwar policy in Hungary. As Count István Bethlen, a delegation member and future Prime Minister of Hungary between 1921 and 1931, put it: "The activity of the Hungarian peace delegation in Paris will be grounds for referring later to all the objections we presented, to which no attention was given, thus confirming that the solution for our fate lies in our own hands" [A magyar békedelegáció párizsi tevékenysége egy jogcím lesz arra, hogy késöbb hivatkozhatunk mindezen elöadott ellenvetéseinkre, amelyek meghallgatásra nem találtak, és így a saját erönkben látjuk további sorsunk megoldását] (cited in Romsics 2007: 119). Teleki, who was one of the leading geographers of the interwar period, and who served not only as the chief geographer of the peace preparations, but also as Prime Minister (1920-21 and 1939-41), Minister of Foreign Affairs (1920-21), and Minister of Religion and Education (193839), expressed similar views. As he formulated in his 1920 inaugural speech as Minister of Foreign Affairs (he held this post simultaneously with his position as Prime Minister): "The weight of these arguments, however-and we knew it when we edited it, and know it today, too-served less the moment but the future, and put right the omissions of the past" [Ezeknek az argumentumoknak a tömege azonban—és ezt tudtuk akkor, amikor szerkesztettük, és tudjuk ma is—nem annyira a pillanatnak, mint a jövőnek szolgált és pótolta a múlt mulasztásait] (Ablonczy 2000: 38-39).

These words also referred to geography. To compensate for what was considered an insufficient geographical substantiation and articulation of Hungarian political goals before and during World War I, the number of geography departments and geographical research institutes increased in the postwar period. In 1926 Teleki established the Államtudományi Intézet ['Institute of Political Sciences'], whose objective was to create and evaluate up-to-date statistical information from the neighboring countries in order to legitimate revisionist goals. In the meantime, the 1924 secondary school reforms and the new elementary school curriculum in 1925 put a substantial emphasis on geography and homeland studies (Györi and Gyuris 2012: 111).

Considerable efforts were also made to popularize geographical arguments against the new national boundaries. This drive began as early as November 1918, when Teleki played an important role in organizing the Magyarország Területi Épségének Védelmi Ligája ['League for Protecting the Territorial Integrity of Hungary'] or Terïletvédelmi Liga ['League for Protecting Territory'] (TEVÉL) (Hajdú 2000). The renowned physical geographer Lajos Lóczy—a former president of the Hungarian Geographical Society (1891-93 and 1905-14) —was elected its first president (Fodor 2006: 673-677, 679). The League also gained massive support from MFT (Hajdú 2000), and contributed significantly to the dissemination of geopolitical propaganda both in Hungary and abroad. Hence, although the League was dissolved after the ratification of the Trianon Peace Treaty (Hajdú 2000), it played a crucial role in introducing geographical arguments for territorial revision into the public revisionary discourse, which itself became, and in the entire interwar period remained, highly geographical (Györi 2011: 295; Györi and Gyuris 2012: 113). In sum, geography as a discipline gained a privileged position in Hungary after World War I, and it was now expected to actively contribute to justifying revisionary goals, mainly through an extensive use of statistics and thematic cartography. 
Gyuris, Ferenc. "Human Geography, Cartography, and Statistics: A Toolkit for Geopolitical Goals in Hungary until World War II." Hungarian Cultural Studies. e-Journal of the American Hungarian Educators Association, Volume 7 (2014): http://ahea.pitt.edu DOI: 10.5195/ahea.2014.173

\section{Geographical Arguments in the Service of Revisionary Goals}

In terms of justifying revisionist goals, Hungarian human geography in the interwar period followed a twofold strategy. It was aimed, on the one hand, at legitimizing the historical boundaries of the country and presenting their restitution as both desirable and necessary. On the other hand, it left no stone unturned to explain what was claimed to be the "bad", "unnatural," and thus unsustainable nature of the new boundaries determined at the peace conference. Some of the arguments mobilized were new, while many of them were based on concepts already present in Hungarian geographical thought since the prewar period. The presentation and dissemination of both sorts of arguments relied heavily on novel methods of statistical analysis and thematic cartography. It is telling that, in Földrajzi Közlemények ['Geographical Review'], articles published up to the early 1920s very rarely employed basic descriptive statistics, while throughout the interwar period, the use of new and sophisticated statistical methods became rather widespread (Gyuris 2009: 163-164). Teleki and his close colleagues, in fact, published articles explicitly dealing with methodical issues of thematic cartography and statistics in human geography (Teleki 1922, Fodor 1925). Reflecting on this shift, this section of the paper will provide an overview of some of the fundamental arguments that geographers used to justify revisionist politics, and will look specifically and some typical (and in most cases tendentious) thematic maps and charts.

A major influence on interwar Hungarian geography was the emphasis that was placed on illustrating and proving both the physical and natural unity of Greater Hungary in the preTrianon period. Focusing on the natural and near perfect borders created by nature itself within the Carpathian Basin, this idea went back to well before the Great War, and even existed prior to the institutionalization of scientific geography in Hungary. Written before he had been appointed the first professor of geography in Hungary, for example, János Hunfalvy had already formulated the idea of a geographically unified nation in his A Magyar Birodalom természeti viszonyainak leírása ['Description of the natural conditions of the Hungarian Empire'], published in 1863. He underscored that "the Hungarian Empire is in general a geographical individuality with a clearly expressed character in its natural conditions; its boundaries are, thus, with a few exceptions, natural, i.e. they are marked by mountain ridges and rivers" [A magyar birodalom általában véve természeti viszonyaiban világosan kifejezett jelemmel biró, földirati egyedség; határai tehát, kevés kivétellel természetesek, azaz hegygerinczek és folyók által jelölvék.] (Hunfalvy 1863: 112). The concept became a cornerstone of Hungarian geographical thought, and gained more importance as it could easily be presented in relief maps with the dark brown curve of the Carpathian Mountains around the green lowlands of the Carpathian Basin. After 1920, especially popular were relief maps indicating the boundaries of Greater Hungary and, usually with dashed or dotted lines, the new boundaries. Wall maps of this sort were hanging on the walls of virtually all schoolrooms in interwar Hungary as mediators of revisionist propaganda (Krasznai 2012). Even more convincing were bird's-eye view relief maps that emphasized the "perfect" physical geographical unity of the Carpathian Basin (Fig. 1). These maps, however, were more difficult to produce, and therefore much less widespread. 


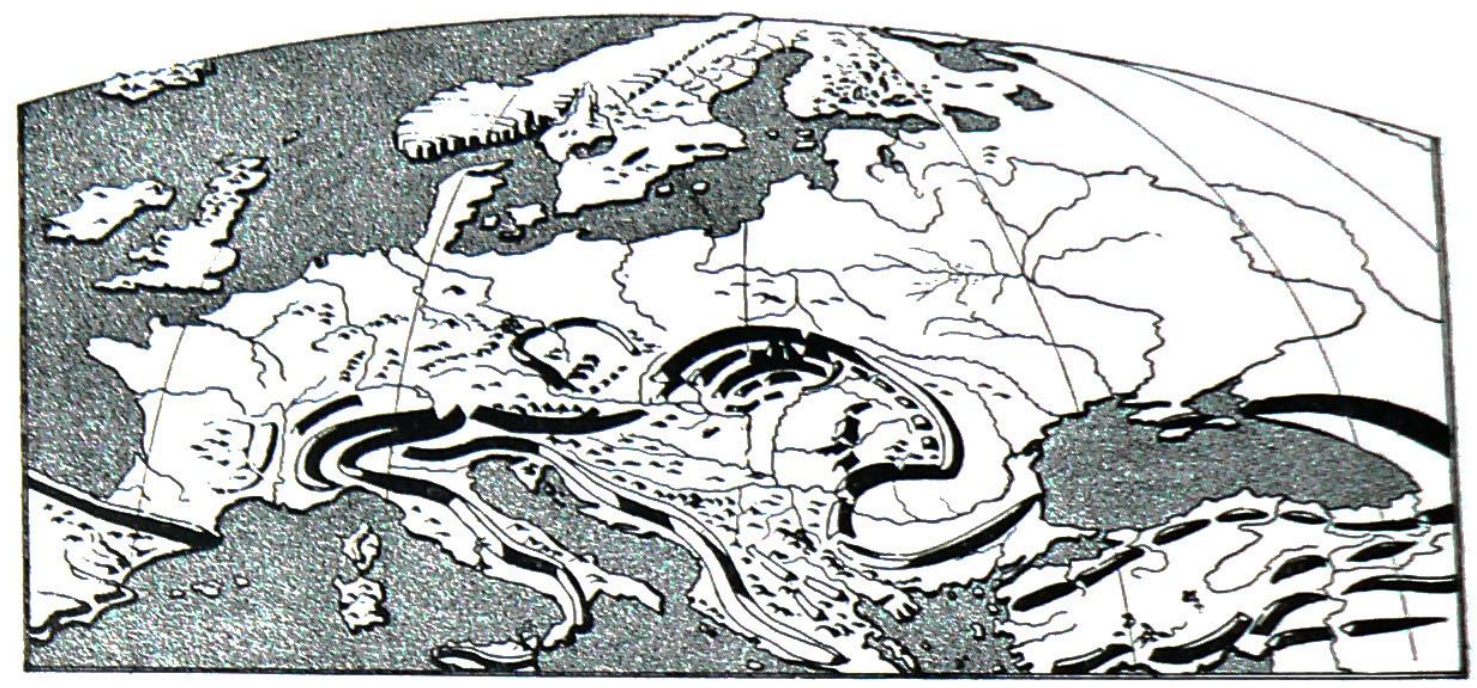

Fig. 1 A bird's-eye view relief map of Europe, aimed at stressing the perfect and, in Europe, unrivaled physical unity of Greater Hungary. Adapted from Prinz (1936: 15).

The hydrological unity of Greater Hungary was another frequently cited argument in geography, both before and after World War I. In fact, the historical territory of the country was largely identical to the drainage system of the central section of the Danube River and its tributaries. In the words of Gyula Prinz, who had to leave the University of Pozsony when it became detached from Hungary after the Trianon Peace Treaty, and who moved to the University of Pécs in 1923: "One of the most beautiful expressions of the country's geographical unity is the spatial shape of its drainage network. If it is true that the unity of the Hungarian landscape is distinct from its neighbors, just as the unity of the Hungarian people is an example of a clearly defined unit, then this unity is a manifestation of the hydrological network" $[\mathrm{Az}$ ország földrajzi egységének egyik legszebb kifejezése folyóvízi hálózatának térbeli alakja. Ha igaz az, hogy a magyar föld éppenúgy a szomszédságától elütő természeti egység, mint amilyen élesen elhatárolt népi egység például a magyarság, akkor ennek a vízrajzi hálózatban is kifejezésre kell jutnia] (Prinz 1938: 189). Given the specific physical and hydrological features of the Carpathian Basin, Hungarian geographers tendentiously referred to Greater Hungary even before WWI as an "ideal" formation in terms of physical geography (Keményfi 2006: 419), and hydrogeography (Keményfi 2008: 114-125). These views were amplified in the interwar period by Prinz's "Tisia" concept about the tectonic development of the Carpathian Basin (first published in Prinz 1926). Here he argued that a large crystallized massive, once existing where the Great Hungarian Plain is today, "folded up" the Carpathian Mountains. Thus, he suggested that the physical and, as a consequence, the political unity of Greater Hungary had been determined by tectonic processes that occurred millions of years earlier (Keményfi 2006). In the light of these arguments, it is no wonder that many geographers spoke about the restoration of historical boundaries after Trianon as a scientific necessity. For instance, the geomorphologist Jenő Cholnoky, President of the Hungarian Geographical Society from 1914 until the end of World War II, and head of the Department of Geography at the Royal Hungarian Pázmány Péter University [Királyi Magyar Pázmány Péter Tudományegyetem] in Budapest between 1921-40 (Fodor 2006: 532-535), wrote about Greater Hungary as the territory "which belonged to us for a 
Gyuris, Ferenc. "Human Geography, Cartography, and Statistics: A Toolkit for Geopolitical Goals in Hungary until World War II." Hungarian Cultural Studies. e-Journal of the American Hungarian Educators Association, Volume 7 (2014): http://ahea.pitt.edu DOI: 10.5195/ahea.2014.173

thousand years and necessarily will belong to us again given the relentless consistency of natural laws" [ami ezer esztendeig a mienk volt s föltétlenül megint a mienk lesz a természettörvények kérlelhetetlen következetességével] (Cholnoky 1937: 5).

During the preparation for the peace negotiations, the Hungarian delegation developed an even more general concept. Although Hungarian geographers had traditionally been influenced by their German counterparts (Györi 2001), Teleki's interests shifted towards the specific approach of French géographie humaine ['human geography'] as early as the prewar period (Györi and Gyuris 2012: 112). The human geographical tradition defined as its main goal the identification and analysis of regions as specific outcomes of the interaction between nature and society. In the lead up to the peace negotiations after World War I, Teleki and the Hungarian elite were convinced that the French would play a decisive role in determining the outcome of the talks, and the geographical shape of postwar Europe. Teleki and his colleagues therefore deemed it desirable to intensify their adoption of the approaches and language of thenmainstream French geographers. This assimilation of French geographical thinking to Hungarian political needs shaped the arguments the Hungarians made against the new boundaries forged by the Treaty of Trianon, and provided the scientific basis for their claims that Greater Hungary was a perfect region whose division would be thus against the laws of nature and actual social circumstances. This argument was already reflected in the 1918 manifesto of the Hungarian Geographical Society (Magyar Földrajzi Társaság, 1918), with the French geographer and founder of the géographie humaine approach, Paul Vidal de la Blache, becoming the most cited person. For strategic considerations, the manifesto also contained many references to Emmanuel de Martonne, a prominent disciple and son-in-law of Vidal, and secretary of the French Comité d'études (Krasznai 2003: 354-355). Similar arguments were made at the peace negotiations by the non-geographer Count Albert Apponyi, leader of the Hungarian delegation and former Minister of Religion and Education (1906-10 and 1917-18). Apponyi put strong emphasis on the geographical unity of Greater Hungary and, making reference to the words of the nineteenthcentury French geographer Elisée Reclus (in particular his 1878 Nouvelle géographie universelle ['New Universal Geography']), praised the prewar Kingdom as "a perfect geographical unit unexampled in Europe" [oly tökéletes földrajzi egység, amely Európában egyedül áll] (cited in Romsics 2007: 174). Referring to French representatives of the géographie humaine and adapting their language and approach remained a basic feature of the works of Teleki and his close colleagues and disciples throughout the interwar period (Györi and Gyuris 2012: 112-113). Meanwhile, virtually every geographer who was focused on the (sub)regions of the country depicted their regions as having been bisected by the postwar boundaries, and drew on their maps lines splitting the subregions, frequently down the middle, to stress the "erroneous" nature of the new territorial order (Györi 2007).

At this point it is important to underscore, however, that the principles most interwar Hungarian geographers-especially those belonging to the Teleki school—constantly referred to, could also be utilized to serve profoundly different interests in other countries. Building on his own work in Wallachia, for example, Emmanuel de Martonne outlined what he claimed to be "a Romanian region," one that he himself identified as an integral unity of mountains, hills, and lowlands. Based on this idea, he argued that Transylvania as a region with mountains in the center, surrounded by hills and lowlands, was the Romanian region "par excellence" (de Martonne 1921: 20, cited in Krasznai 2003: 351-352). This argument, not surprisingly, was utilized extensively by the Romanian delegation during the peace conference in order to justify their claim to the territory (Krasznai 2003: 351). Similarly, whereas Hungarian geographers 
Gyuris, Ferenc. "Human Geography, Cartography, and Statistics: A Toolkit for Geopolitical Goals in Hungary until World War II." Hungarian Cultural Studies. e-Journal of the American Hungarian Educators Association, Volume 7 (2014): http://ahea.pitt.edu DOI: 10.5195/ahea.2014.173

referred to Greater Hungary in the Carpathian Basin as a nearly perfect round-shaped geographical unit, de Martonne stressed that, by changing borders, the prewar Romanian "setsquare" would be replaced by a "round and perfect" shape (Palsky 2002: 113).

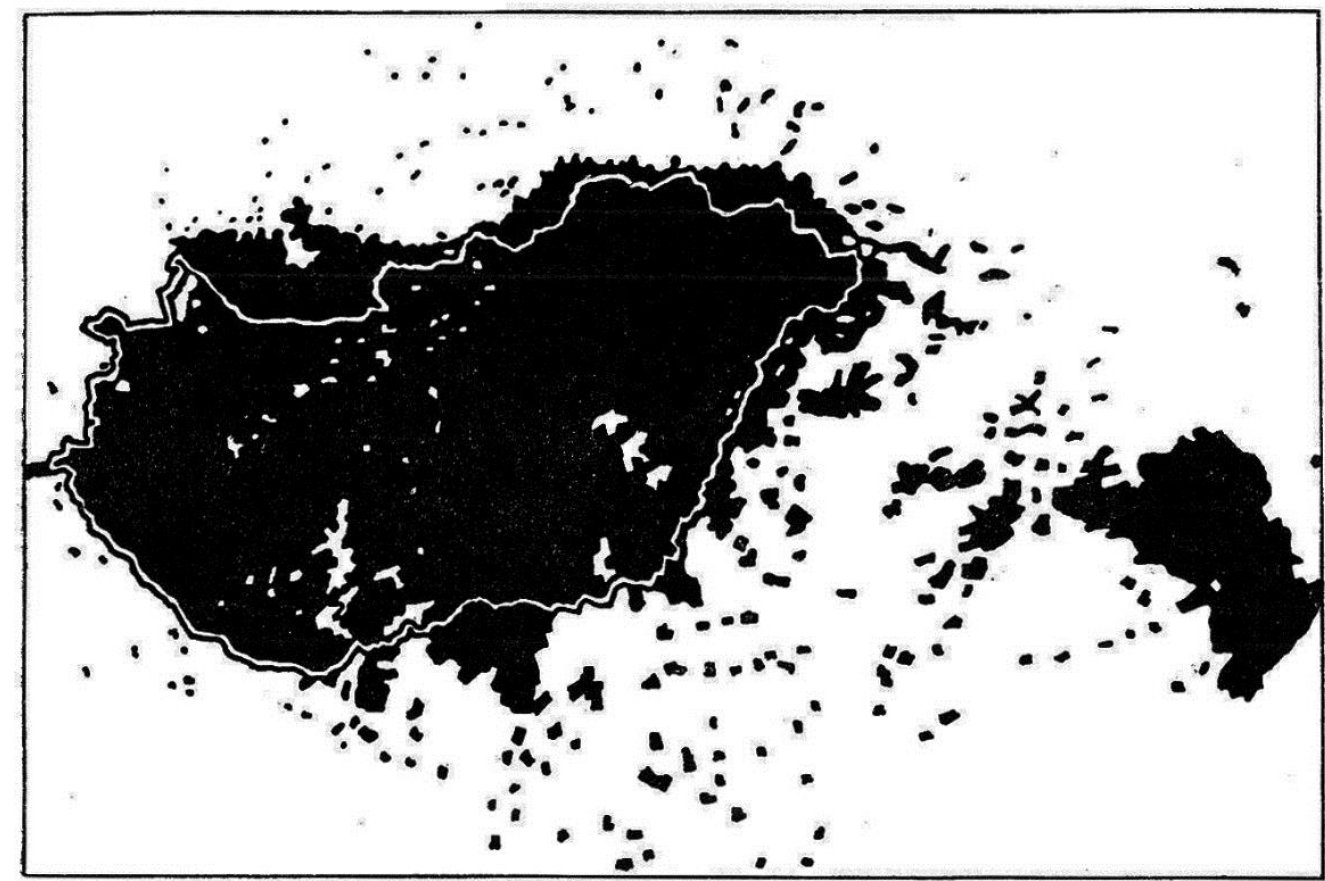

Fig. 2 Prinz's map detailing the discrepancy between areas inhabited by native Hungarian speakers (black) and the boundaries of Hungary after 1920 (white line). Adapted from Prinz (1938: 257).

Beyond physical geographical considerations, Hungarian geographers employed a number of social arguments to expose what they claimed to be the unjust and unsustainable boundaries set by the Trianon Peace Treaty. A main point was that the new borders contradicted U.S. president Woodrow Wilson's Fourteen Points aimed at guaranteeing the independence and territorial integrity of all nations. Given that almost one-third of the ethnic Hungarian population, or approximately 3.2 million inhabitants, were left outside the country's new boundaries, the peace settlement forced on Hungary could hardly be seen to be fair (Romsics 2007: 161). This demographic fact was stressed again and again by interwar geographers in Hungary, with maps revealing the discrepancy between "the dispersion of the linguistic nation" and the territory of postwar Hungary (Fig. 2). Their goal, it is important to point out, however, was not to create new borders based on ethnic groupings. Given that large areas of Greater Hungary were in fact dominated by non-Hungarian people, a rigorous application of the "ethnic principle" would still have led to significant territorial losses for Hungary. Therefore, this strategy was unacceptable for the interwar nationalist-conservative regime. It was also unacceptable for the vast majority of Hungarian geographers allied with the political leadership (Györi and Gyuris 2012: 112), and was tolerable only for the regime's left-wing and liberal opposition (Romsics 2010: 239). Hence, as early as 1918, the geographically-inclined authors of Pro Hungaria stressed that, on the table at the peace conference, "it shouldn't be the nationality map, but rather the relief and drainage map that should be stretched out" [nem a nemzetiségi, hanem a hegy-és vízrajzi térképet kell 
Gyuris, Ferenc. "Human Geography, Cartography, and Statistics: A Toolkit for Geopolitical Goals in Hungary until World War II." Hungarian Cultural Studies. e-Journal of the American Hungarian Educators Association, Volume 7 (2014): http://ahea.pitt.edu DOI: 10.5195/ahea.2014.173

kiteríteni] (cited in Hajdú 2000). (It is worth mentioning that representatives of the future Little Entente, i.e., Czechoslovakia, Romania and Yugoslavia, were also not interested in rigorously applying the ethnic principle on the basis of nationality statistics. This would have resulted for them in less territorial gains after the war. They argued that nationality statistics from prewar Hungary were manipulative in that they identified many non-Hungarian people as Hungarians. This view was expressed among others by de Martonne [Bowd 2011: 115] and by the French diplomat Philippe Berthelot at the peace negotiations [Romsics 2007: 178].)

Geographers, therefore, instead tended to point out why the application of the ethnic principle was impossible in the Carpathian Basin. For the peace negotiations, Teleki compiled an ethnographic map of Greater Hungary commonly referred to as the Carte Rouge ['Red Map'], with red used to indicate areas with an ethnic Hungarian majority (Fig. 3). The map was intended to depict ethnic relations as precisely as possible, and to correct some contestable features of "traditional" ethnic maps. These more traditional maps usually mark each area with a color representing the dominant nationality in that space. One of the challenges that arises from this rather simplistic form of map making is that it is difficult to represent a multiethnic region using blocks of color. Hence, mixed population areas seem homogeneous and population density is not reflected. A loosely populated rural district with 100,000 inhabitants of nationality 'A', for example, might be hundreds of times larger in area than a city with 100,000 inhabitants of nationality ' $\mathrm{B}$ '. This method underemphasizes the nationalities mostly concentrated in cities (for example the Hungarians), and overemphasizes nationalities forming the majority in vast areas with low population density (the Romanians). To cure these problems, Teleki depicted each nationality with an area proportional to its actual population size, with each square kilometer representing 100 people. The resulting map was statistically much more correct than most of its counterparts before, which should not be underestimated given the vast number of maps serving the political interests of neighboring countries even at the cost of remarkable statistical distortions. (A remarkable example is a 1919 map prepared for the peace talks by Jules-Eugène Pichon, former French lector at the University of Prague and a member of Comité d'études, which indicated the areas Hungary later surrendered to Czechoslovakia as solely non-Hungarian, in spite of the 1910 census registering 30.3\% as Hungarian, see Romsics 2007: 58.). According to Teleki's map, people living in areas with a population density below 100 people/sq.km, however, had to be marked not exactly where they were actually living. Similarly, people of different nationalities living in the same area had to be depicted at different locations. This opened the door for subjective cartographic solutions, which simultaneously emphasized the existence of vast uninhabited areas along the Carpathian Mountains (which definitely existed but were in fact smaller) and a "compactness" of inhabited areas in Greater Hungary, and an extremely fragmented ethnic pattern in many districts, suggesting that a righteous setting of boundaries in accordance with the ethnic principle was practically impossible (an in-depth analysis of the Carte rouge is provided by Krasznai 2003: 356-359). 
Gyuris, Ferenc. "Human Geography, Cartography, and Statistics: A Toolkit for Geopolitical Goals in Hungary until World War II." Hungarian Cultural Studies. e-Journal of the American Hungarian Educators Association, Volume 7 (2014): http://ahea.pitt.edu DOI: 10.5195/ahea.2014.173

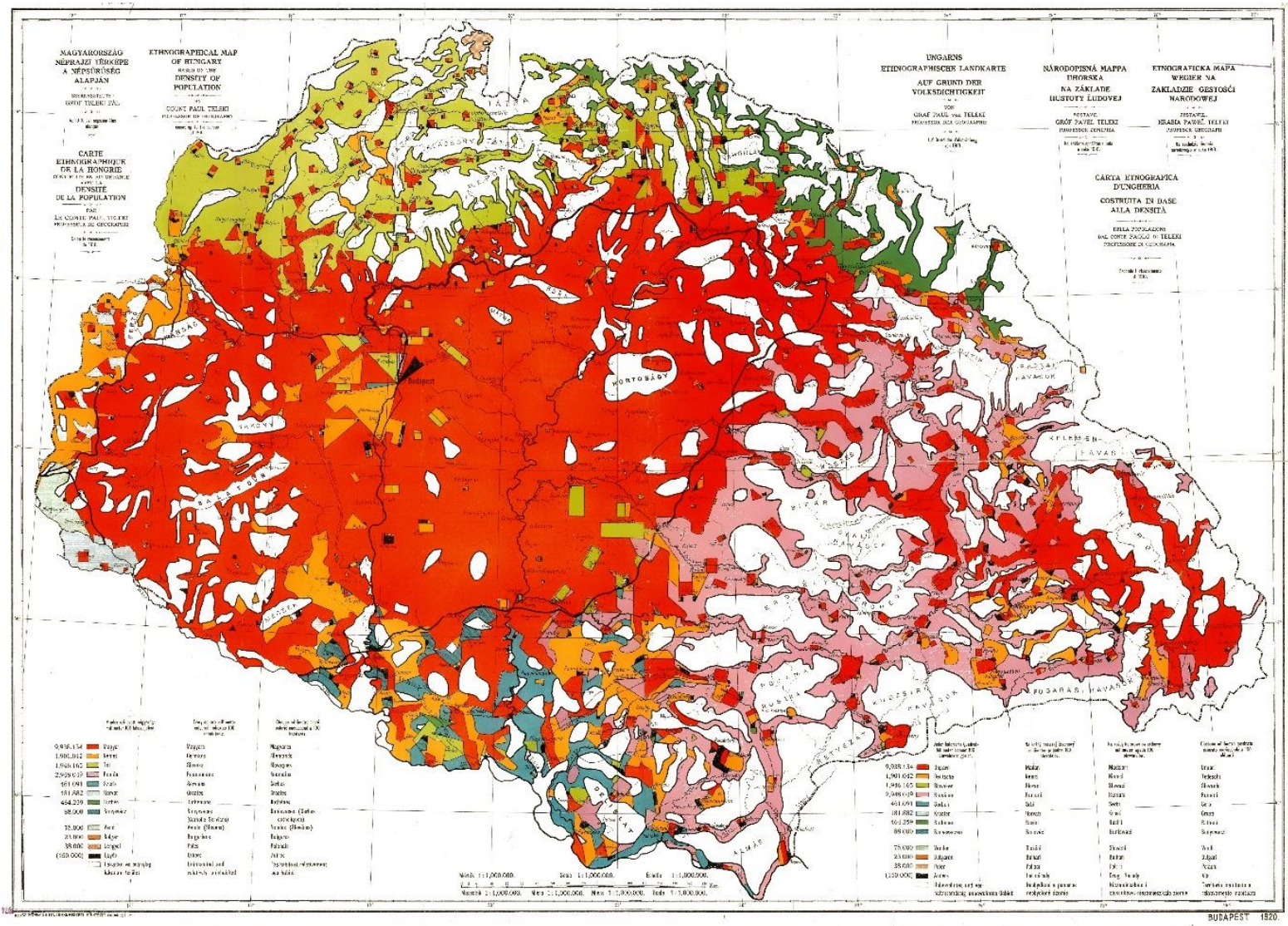

Fig. 3 Pál Teleki’s Carte Rouge depicting ethnographical conditions in Greater Hungary, with Hungarian ethnic population marked by red. Adapted from

http://upload.wikimedia.org/wikipedia/commons/e/ea/Ethnographic_map_of_hungary_1910_by_ teleki_carte_rouge.jpg

In fact, as Krasznai underscores, Teleki was not the only geographer who tried to solve such problems. De Martonne also created a map, which was published in a 1919 atlas alongside articles of Comité d'études. One contestable aspect of this map was that minorities were depicted only where the dominant nationality did not form at least $75 \%$ of the population. Another point of contention was that nationality structure was presented by pie charts for cities, but by color shading for rural areas, thus visually overemphasizing the nationalities dominant in rural districts. As a result, de Martonne's map was as much praised in France and Romania as Teleki's was in Hungary. In the meantime, both were based on almost identical statistical data, but conveyed remarkably different impressions in accordance with their underlying political motivations (Krasznai 2003: 356-360) and national myths (Krasznai 2012: 77-79). (In fact, from the late 1930s onwards, Teleki's disciples tended to work with cartograms where each settlement was represented by a pie chart showing both the number of inhabitants and ethnic division (see Kocsis 2008: 58-67). This method produced a much more accurate image about ethnic relations, but, since it reflected the complexity of the issue, it could hardly contribute to the political goal of identifying where "ideal" ethnic boundaries could have been set.) 
Gyuris, Ferenc. "Human Geography, Cartography, and Statistics: A Toolkit for Geopolitical Goals in Hungary until World War II." Hungarian Cultural Studies. e-Journal of the American Hungarian Educators Association, Volume 7 (2014): http://ahea.pitt.edu DOI: 10.5195/ahea.2014.173

Another important point in interwar Hungarian geography was the complimentary economic nature of the various parts of Greater Hungary, which were now isolated from each other due to the new boundaries and anti-Hungarian trade policies of Czechoslovakia, Romania, and Yugoslavia. This argument had emerged already during the peace negotiations. Apponyi, as head of the Hungarian delegation, did not forget to emphasize the "economic unity" of prewar Hungary (see Romsics 2007: 174). Thanks to the use of statistics and new methods in geographical visualization, this issue could also be presented clearly. In terms of illustrating economic geography, the greatest achievements were later made by Andás Rónai beginning in the late 1930s. As a disciple of Teleki, Rónai was named director of the Institute of Political Sciences in 1939, and one year later was appointed as university professor of political geography in Budapest (Dövényi 2008: 12). Rónai had the explicit goal to "reveal and make [post-Trianon geographical issues] as understandable and striking as possible, even for a non-expert" [felfedni és a nem szakember számára is minél érthetőbbé és szembeötlöbbé tenni] (Rónai 1936: 28). For Rónai, of key importance was to make the general public aware of the contrast between the "ideal" political and economic geographical conditions that prevailed in Greater Hungary prior to the war, and the lack of such conditions under the new territorial order. He took the stance, also compatible with the géographie humaine approach, that a "harmonious" region and country should not be homogeneous, but a complex network of various areas complementing each other. On the basis of production and consumption statistics for raw materials produced in agriculture or mining in 1914-15, Rónai argued that prewar Hungary produced a surplus in most products selected, while the deficit for other products was also moderate (Fig.4). For the five regions that would later belong to different countries after 1920, however, enormous surpluses and deficits for different products were coexistent. Rónai underscored the mutually negative outcomes pointing out that the new situation "erodes on both sides the potential of consumption and the standard of living, and reduces economic trade" [mindkét oldalon a fogyasztási képességet és életszínvonalat rontja s a gazdasági forgalmat csökkenti] (Rónai 1936: 27). The conclusion was clear: "Here's a state territory ideal by nature, into which human hands have ignorantly intervened" [Ime egy természettöl fogva ideális államterület, amelybe az emberi kéz tudatlanul nyúlt bele] (27). In general, Rónai provided very vivid insight into the economic relations between the regions of Greater Hungary that had fallen apart. One should stress here again, however, that the logic of this reasoning was not unique to Hungarian geography. In fact, de Martonne emphasized how well the various parts of postwar Romania could complement each other in terms of the economy. For example, the lowlands (such as the Banat) would produce crops for the mountain districts, while the latter would provide the former with wood, building stones and water (Boulineau 2001). Hence, what Rónai mobilized as an argument to delegitimize the postwar boundaries of Hungary was in de Martonne's hands a forceful justification of the new order. 


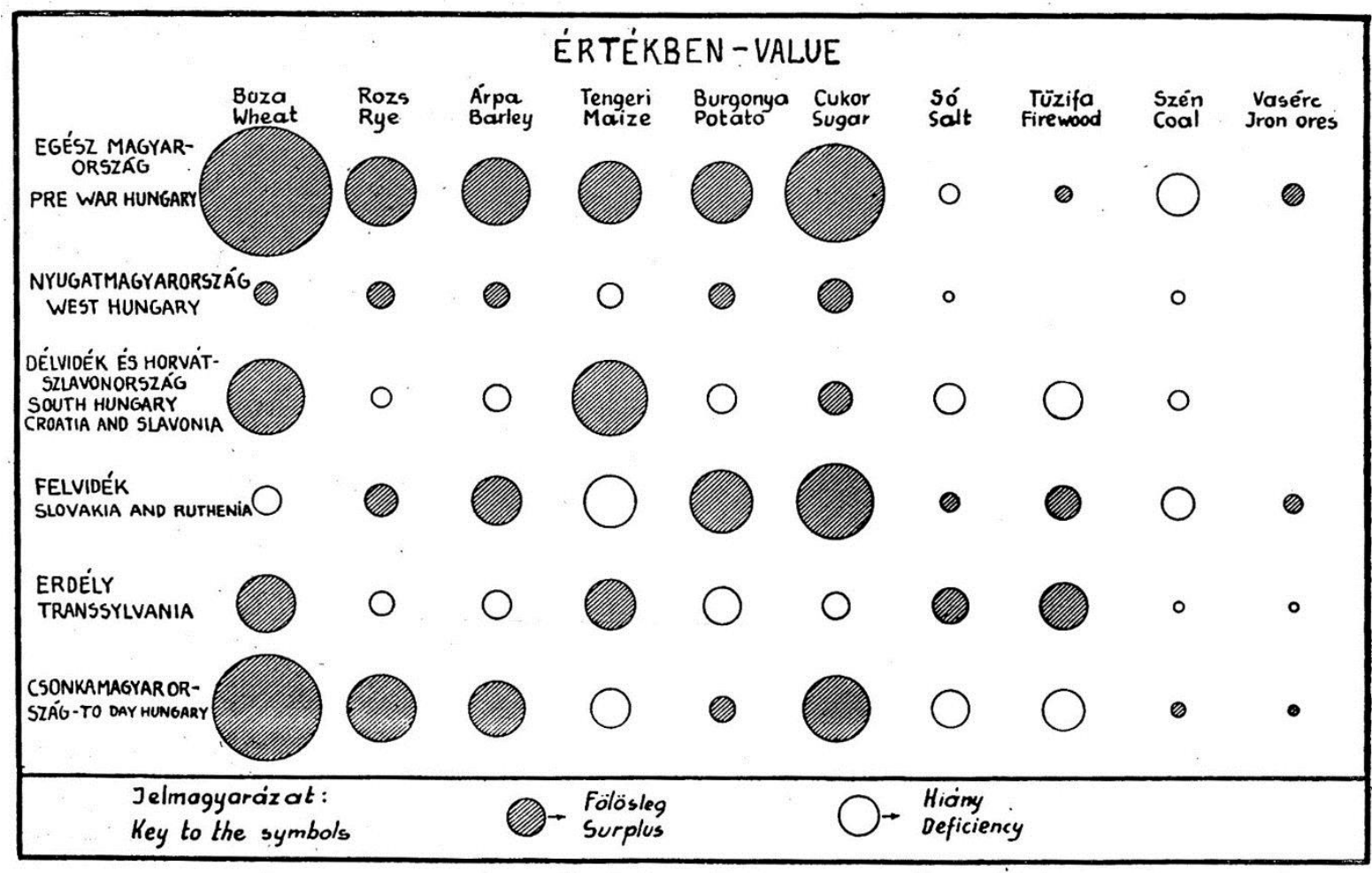

Fig. 4 Production and consumption of some basic raw materials in Greater Hungary and the five territories it was divided into. Adapted from Rónai (1936: 25).

To justify Hungary's revisionist goals during the interwar period, Hungarian geographers also mobilized the idea that Greater Hungary had an "ideal" spatial structure, which they contrasted to what they claimed to be the "artificial" and "unsustainable" characteristics of Czechoslovakia, Romania, and Yugoslavia. A most remarkable example of this was a study by Rónai (1936), in which he presented cross-sections of Greater Hungary and postwar Romania and Yugoslavia. Along the cross-section, each region was represented by a column proportional in height to the regional value of the population density. The resulting maps for Greater Hungary, drawn along the four different cardinal directions, all showed the highest population density close to the country's geographical center, with smaller and slightly decreasing values toward the peripheries (Fig. 5). For Yugoslavia and especially for Romania, Rónai's maps suggested population density either changing from one region to another without any regularity, or showing the highest values in the periphery surrounding poorly inhabited central areas (Fig. 6). It is worth noting that Rónai provided no map at all for Czechoslovakia. In his sarcastic words "We have to entrust the imagining of a similar picture of Czechoslovakia to the reader [...], because depicting this endlessly long ribbon-like state territory on a sheet of this size presents technical obstacles" [Csehszlovákia ilynemü képének elképzelését az olvasó fantáziájára kell biznunk [...], mert e pántlikaszerüen végtelen hosszú államterület ábrázolása ekkora papiroson technikai akadályokba ütközik] (Rónai 1936: 13). 

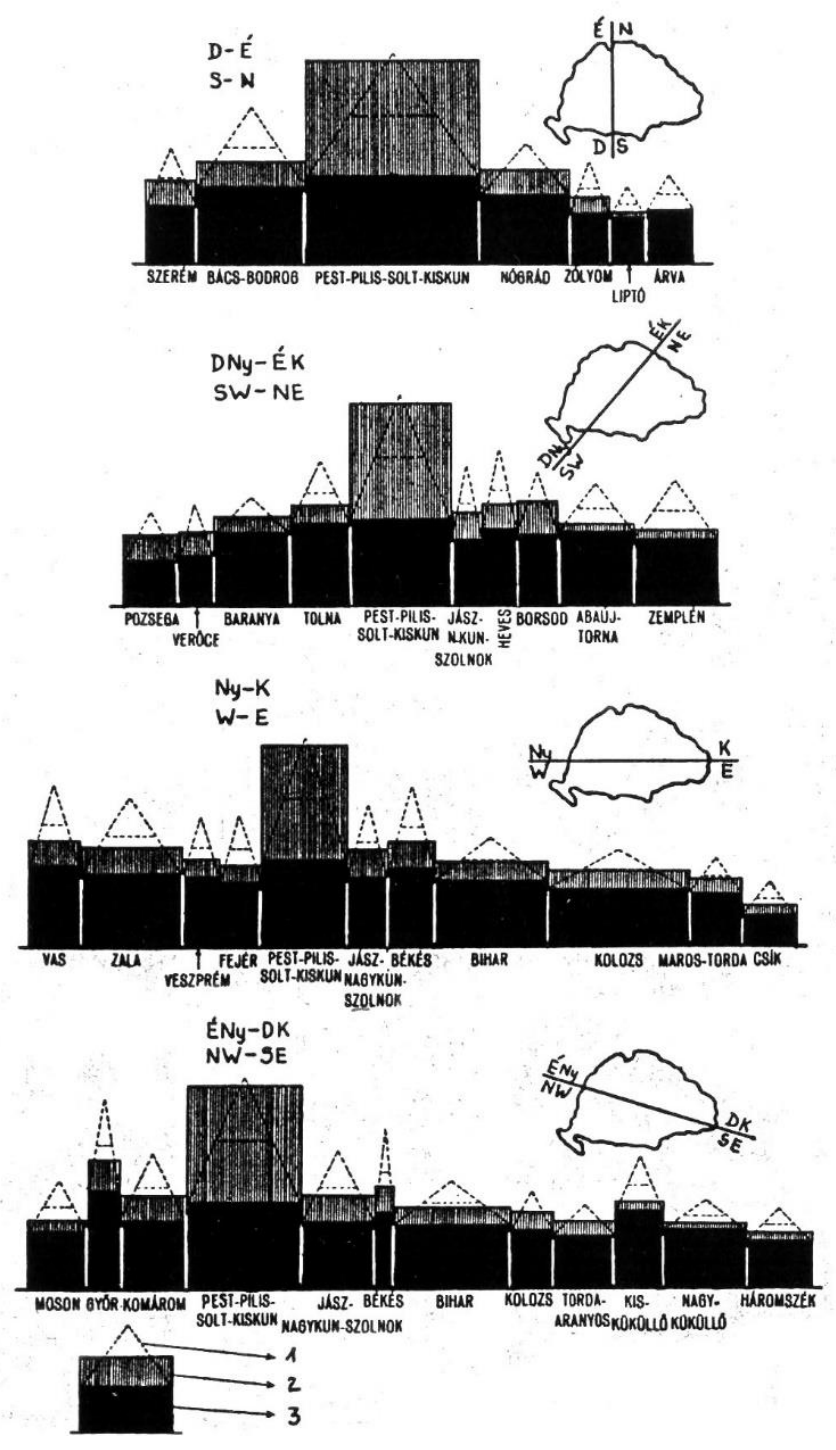

Fig. 5 Cross-sections of Greater Hungary on the basis of regional population density values. Adapted from Rónai (1936: 14).

On the basis of these findings Rónai developed a clear argument, one based on the following stance: "Political geographers have identified as a general rule-with both common sense and many other sciences related to the organization of state in full agreement-[that] the division of population in a given state territory is ideal if settlement is the most dense around the center, and steadily declining toward the sides" [A politikai földrajzírók általános szabálynak állapították meg—s ezt a megállapítást a józan ész s egy csomó egyéb, az államszervezettel kapcsolatos tudomány mindenképpen indokolja-, ideálisan akkor oszlik el valamely államterület népessége, ha a központ körül legsürübb a település s ez a szélek felé egyenletesen ritkul] (12). In light of this concept and his own statistical results, Rónai came to the conclusion that "the distribution of population in the Carpathian Basin provides a perfect example for a state 
Gyuris, Ferenc. "Human Geography, Cartography, and Statistics: A Toolkit for Geopolitical Goals in Hungary until World War II." Hungarian Cultural Studies. e-Journal of the American Hungarian Educators Association, Volume 7 (2014): http://ahea.pitt.edu DOI: 10.5195/ahea.2014.173

territory with ideal population density" [a Kárpátok medencéjének népességeloszlása az ideális népsürüségü államterület hibátlan példáját szolgáltatja] (13), and confirmed that Greater Hungary was endowed with an "outstanding suitability for a unitary state territory, contrary to the image of territory and population in the states newly created after the world war, which are prime examples for state territories with populations falling apart" [egységes államterületnek való kiváló alkalmasságára, szemben a világháború után teremtett új államok területének és népességének képével, amelyek a széthulló népességü országterületek iskolapéldái] (17). For Romania, he even suggested that it was "simply wonderful: in a north-south direction it is a perfect opposite of the ideal" [egyenesen csodálatos: É-D-i irányban tökéletes ellentéte az ideálisnak] (16).

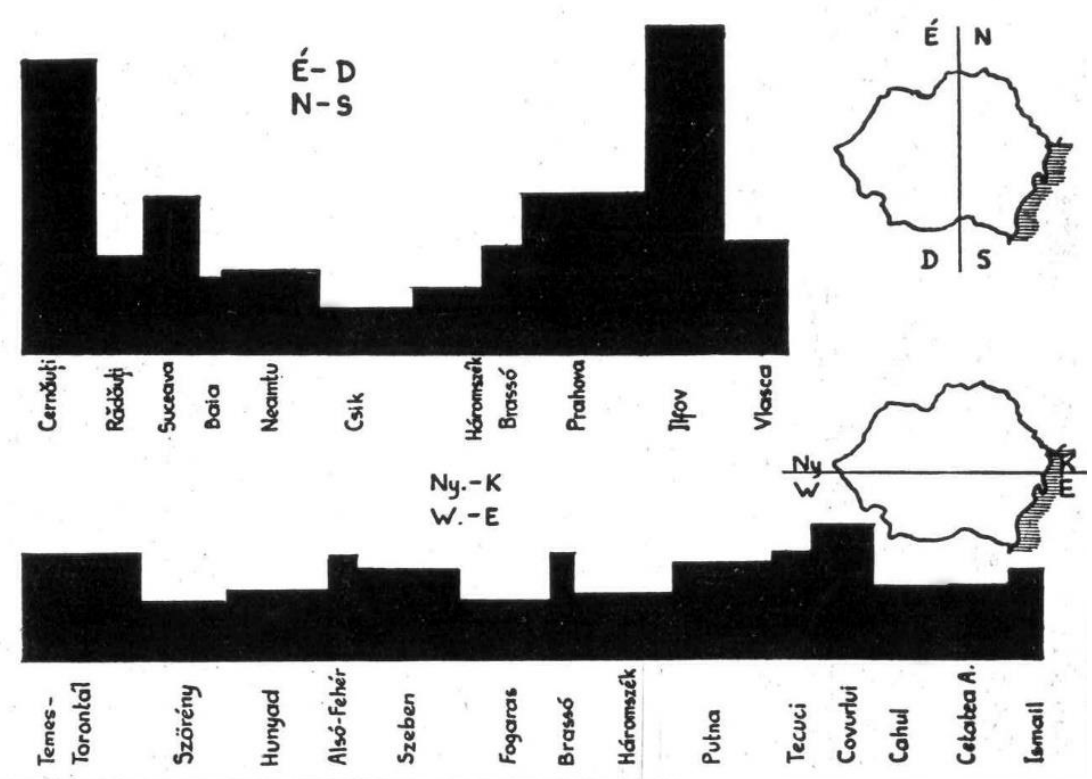

Fig. 6 Cross-sections of postwar Romania on the basis of regional population density values. Adapted from Rónai (1936: 17).

Rónai's argument was, however, contestable at least on two points. First, he did not identify the "political geographers" he was referring to when he claimed that population density decreasing from the center to the periphery is "ideal." For those schooled in this field, however, it is not difficult to see here the influence of the Thünen Model. Johann Heinrich von Thünen was a German landowner who in his 1826 work Der isolierte Staat ['The Isolated State'] analyzed the agricultural regularities of land use. His point was that in a physically homogenous area, agricultural activities would form concentric zones around a dominant center, each zone facilitating activities in order to generate optimal profits. Locational rents were expected to steadily decrease from the center, in accordance with the overall profitability of activities. Although Rónai did not refer to Thünen in his essay explicitly, one can reasonably suspect this link given the currency of Thünen's concept among economic geographers. Moreover, in those years, Rónai's master, Teleki, with the assistance of some of his close colleagues and disciples, studied the spatial order of agricultural development according to the Thünen concept on both the continental as well as global scales (Hajdú 1987: 91). The Thünen model was not about political geography, however. It defined an ideal space to present certain economic regularities, and not to provide a model of "good" settlement to which actual urban networks and political 
Gyuris, Ferenc. "Human Geography, Cartography, and Statistics: A Toolkit for Geopolitical Goals in Hungary until World War II." Hungarian Cultural Studies. e-Journal of the American Hungarian Educators Association, Volume 7 (2014): http://ahea.pitt.edu DOI: 10.5195/ahea.2014.173

divisions should be adapted to. In addition, although Greater Hungary fit Rónai's concept due to its centralized urban network with the capital city, Budapest lying relatively close to the geographical center, most countries of the world would not have fit it. Such "exceptions" include not only a number of countries that have exhibited both historical stability and economic prosperity (especially those with decentralized urban systems such as the United States, Germany, or Switzerland), but also Hungary itself before the late nineteenth century. Perhaps even more critically, Hungary's "fit" was an outcome of selecting a "feasible" scale, the regional one. A local-scale graph, depicting the values of each town and village, would have provided a much more detailed image, one showing differences between local centers and their surroundings as higher and lower columns all over the country, not the simple shape in correspondence with Rónai's concept.

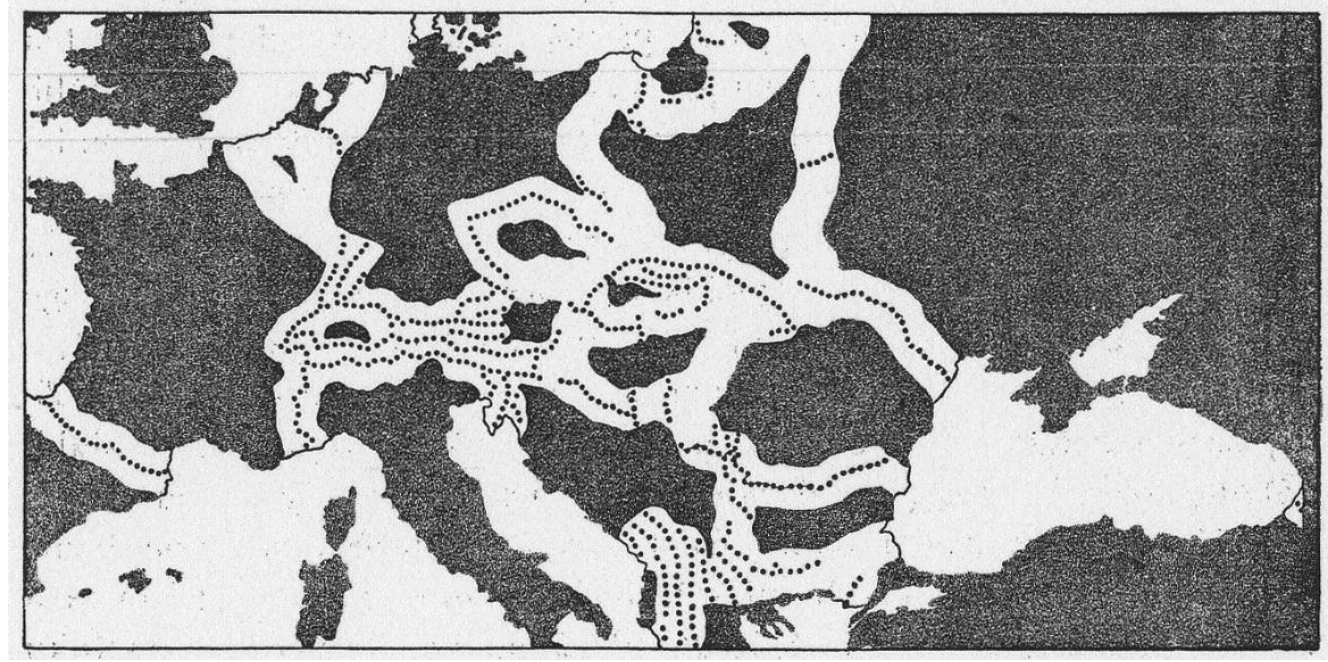

Fig. 7 Border zones (50 km from within the boundaries) in Central Europe and "main defense lines" marked with dots. In Prinz's explanation, the "territory within the border zone indicates the territorial power of each state." Adapted from Prinz (1938: 357).

Interwar geographers in Hungary often referred to challenges of strategic defense after 1920. Even simple maps that noted "main defense lines" [védelmi fóvonalak] (Prinz 1938: 357), the "peripheral" zones (for example, $50 \mathrm{~km}$ from within the national boundary), and "central" zones of each county, made it clear that postwar Central Europe was formed by a set of small countries difficult to defend in times of war (Fig. 7). In terms of statistical analysis, a more sophisticated method was the calculation of népnyomási hányados ['the coefficient of population pressure'], coming from the Druckquotient ['coefficient of pressure'] developed in German geopolitical thought at the turn of the 1910s and 1920s (Rónai 1933: 253). For the original concept, this coefficient resulted for a given country after dividing the entire population of neighboring countries by the population of the given country. This method was adapted both by András Rónai (1933) and Gyula Prinz (1938), which is no surprise given Rónai's specialization in thematic mapping and statistics, and Prinz's reliance on new methods developed in interwar German geography. Rónai even improved upon the concept in order to take into consideration the different lengths of a given country's boundary sections with each of its neighbors (thus attributing different "weights" to the neighbors up to the length of common borders). Finally, he 
Gyuris, Ferenc. "Human Geography, Cartography, and Statistics: A Toolkit for Geopolitical Goals in Hungary until World War II." Hungarian Cultural Studies. e-Journal of the American Hungarian Educators Association, Volume 7 (2014): http://ahea.pitt.edu DOI: 10.5195/ahea.2014.173

found values for each country in postwar Central Europe that he judged high. Rónai also tried to carry out the analysis on another basis, considering not only total population numbers but also ethnic division. He calculated a modified coefficient as follows:

(majority population in neighboring countries in terms of nationality + people with the same nationalities in the given country) $\div$ majority population of the given country.

This method resulted in even higher values of the coefficient for most countries in Central Europe. By this, Rónai's goal was not to stress a specific and "unjust" situation of Hungary, but to turn attention to the considerable tensions within the entire region. In other words, he made an effort to express in the language of numbers that "the disorder of the minority issue multiplies the quantifiable danger to these boundaries that are weak in terms of nationality" [ $e$ nemzetiségileg gyenge határokat fenyegetö veszélyt a kisebbségi kérdés rendezetlensége a számszerüen kimutatható állapotnak is sokszorosára emeli] (Rónai 1933: 260).

To justify the manifold arguments about the sustainability of Greater Hungary resulting from its physical and economic unity as well as defensibility, geographers often referred to the historical stability of the old boundaries. Indeed, the so-called "thousand-year-old borders" played a crucial role in the entire revisionist discourse, even at the level of everyday speech. In fact, given the "traditionalist" approach of the era, just being "old" legitimized the old borders. For geographers, however, the existence of old boundaries was not simply a traditional fact, but rather proof of the fundamental power of the geographical factors they identified. Hence, the stability of the boundaries became a crucial issue for Hungarian political geography, and led to a remarkable map drawn by Rónai for his Középeurópa atlasz ['Atlas of Central Europe'] (Fig. 8). (The atlas itself was a large-scale enterprise to bring together all the geographical arguments that future representatives of Hungary could make at the expected post-World War II peace negotiations. It was finished no earlier than 1945, and was printed only in a few copies (Klinghammer 2008)). The message of the map is clear: the boundaries of Greater Hungary along the Carpathian Mountains displayed a historical stability unmatched in Central Europe. Even the southern boundaries, which did not exist during the Ottoman occupation for a considerable part of the country, proved quite "enduring" compared to most borders in the neighborhood of Hungary.

Rónai's map, however, raises important questions. The most striking issue is that the ridges of the Carpathian Mountains have existed as borders for many hundreds of years indeed, but not always as international boundaries since, in a legal sense, Hungary was not sovereign over the entire 920 years depicted on the map. After gradually becoming part of the Habsburg Empire by the end of the seventeenth century, Habsburg emperors (and, basically, all foreign powers, too) considered and handled Hungary as part of the empire, not as a sovereign state, even if the Hungarian nobility made claims about their country's sovereignty. Hungary regained full and internationally acknowledged independence no earlier than 1918. Hence, for a long time, most sections of the country's borders in the west, north, and northeast were internal boundaries in international eyes, ones that were similar to those of the Lands of the Bohemian Crown after being incorporated into the Austrian Empire (and belonging to the Austro-Hungarian Monarchy between 1867 and 1918). Hence, following the logic Rónai used in the legend, these borders should be marked by dashed lines for this period, while the time intervals of their existence as international boundaries before the Habsburg domination and after 1918 should not be 
Gyuris, Ferenc. "Human Geography, Cartography, and Statistics: A Toolkit for Geopolitical Goals in Hungary until World War II." Hungarian Cultural Studies. e-Journal of the American Hungarian Educators Association, Volume 7 (2014): http://ahea.pitt.edu DOI: 10.5195/ahea.2014.173

summarized. Of course, these borders would then become much less striking, undermining the intended meaning and visual power of the map. (Beyond some other minor details it is also remarkable that Rónai did not depict any borders existing for less than 50 years. Thus, post-WWI boundaries of Hungary remained invisible.)

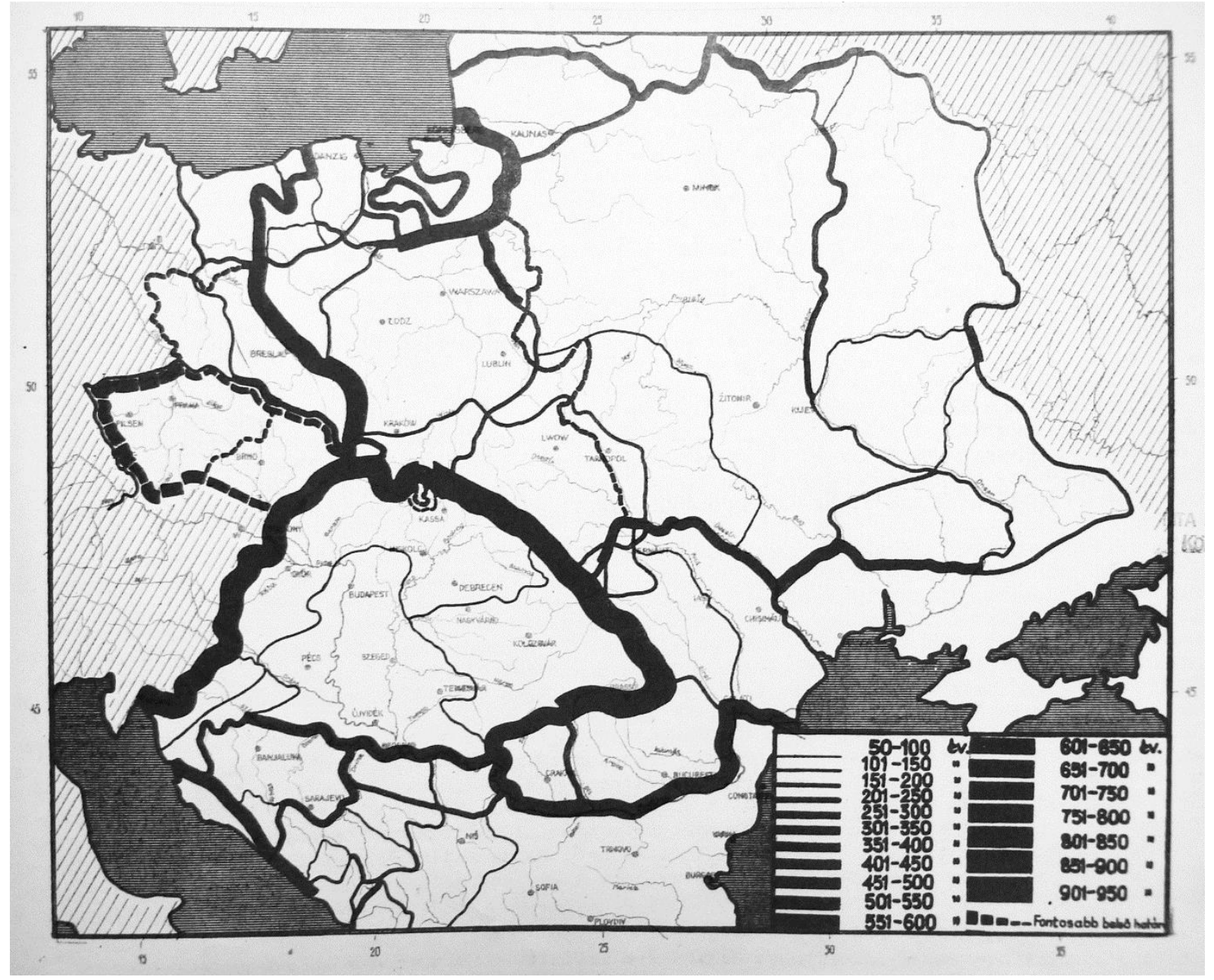

Fig. 8 The stability of "state-frontiers" in Central Europe (1000-1920). Solid lines show how long a given boundary section existed or has existed (categories begin with "50-100 years" and last until "901-950 years"). Dashed lines represent "major inland boundaries". Adapted from Rónai (1945).

Finally, the political discourse in Hungary between the wars became deeply interconnected with a civilizing discourse. In his 1920 speech at the peace negotiations, Apponyi stressed that "the neighboring nations, due to unfortunate events in their histories, joined the family of civilized nations later than us" [a szomszédos népek történelmük szerencsétlen eseményei folytán későbben léptek be a civilizált nemzetek családjába, mint mi], and they "currently stand for the most part at a lower cultural stage" [jelenleg többnyire alacsonyabb kulturális fokon állnak]. Thus, the setting of new boundaries in the future should "not be indifferent to the great cultural values of humankind" [nem közömbös az emberiség nagy 
Gyuris, Ferenc. "Human Geography, Cartography, and Statistics: A Toolkit for Geopolitical Goals in Hungary until World War II." Hungarian Cultural Studies. e-Journal of the American Hungarian Educators Association, Volume 7 (2014): http://ahea.pitt.edu DOI: 10.5195/ahea.2014.173

kulturális érdekei szempontjából] (cited in Romsics 2007: 169-170). In accordance with this argumentation, the interwar regime (and especially Count Kuno Klebelsberg, Minister of Religion and Education between 1922-31) made great efforts to improve education and firmly support national culture in order to strengthen the "cultural advantage" [kultúrfölény] of Hungarian people. This was considered key to bringing the country once again to a position where its power would radiate throughout the entire Carpathian Basin. In the words of Klebelsberg: "today it is mainly not the sword, but culture that can defend the Hungarian homeland and make it great again" [a magyar hazát ma elsösorban nem a kard, hanem a kultúra tarthatja meg és teheti ismét naggyá] (Klebelsberg 1927: 604).

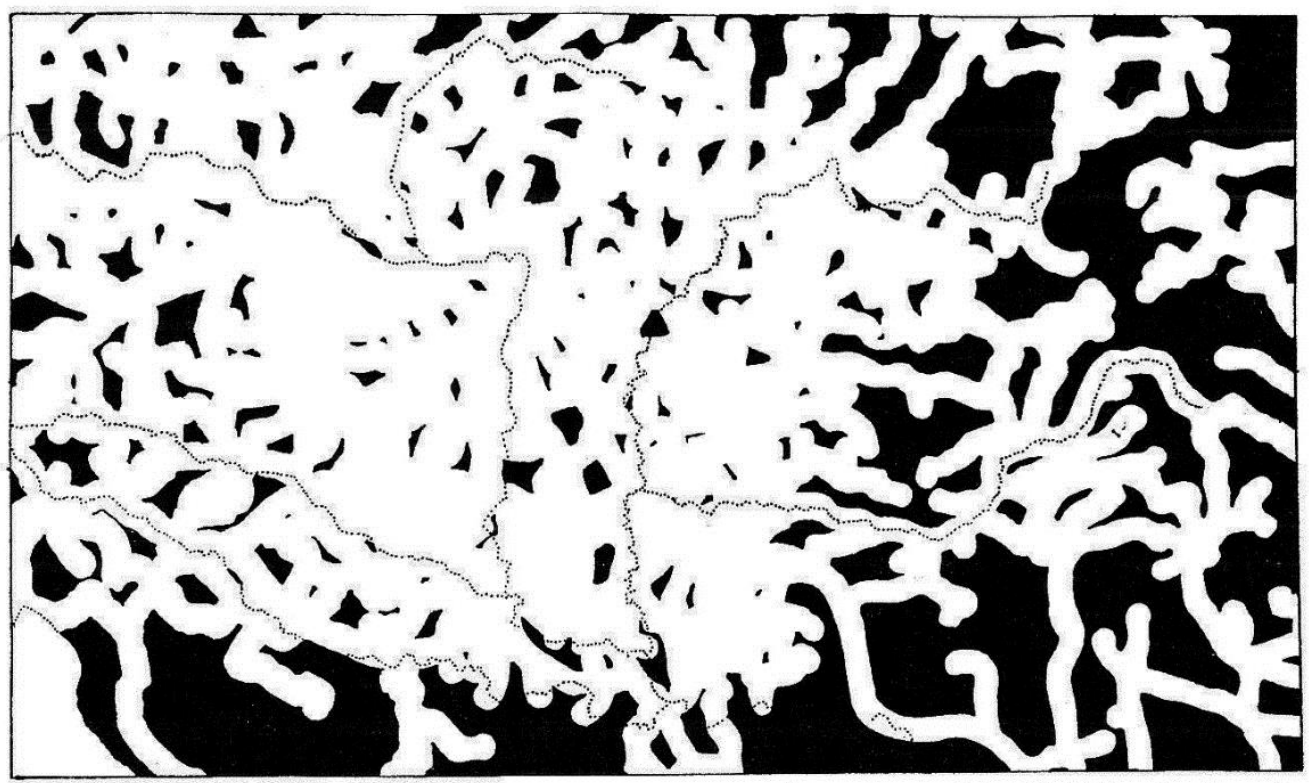

Fig. 9 Districts more than $10 \mathrm{~km}$ away from railway lines, marked by black ("dark patches" in Prinz's words). Dotted lines represent the main rivers. Adapted from Prinz (1938: 96).

Geographers of the interwar period also referred in many works to data that could be utilized to reveal a significant advantage of Greater Hungary over its eastern, southeastern, and southern neighbors, and in some cases even between the areas of prewar Hungary dominated by Hungarian and non-Hungarian nationalities. Two statistical indicators were of special importance here due to their relatively precise statistical collection and easy visualization: literacy rates and railway density. A remarkable example for the latter is a map by Gyula Prinz, who used white lines on a black background to mark the areas lying within $10 \mathrm{~km}$ of railway lines (Fig. 9). The harsh contrast had an explicit message: "the vast whiteness of the inner country [...] jubilantly advertises the country's advancement, and through this its commonalities with neighboring western countries" [az ország belsejének hatalmas fehérsége [...] ujjongva hirdeti az ország elörehaladottságát és ebben a nyugati szomszéd országokkal való közösségét]. Or, in another interpretation: "it is hard to notice the country's western boundary in this figure. But it is just as easy to notice the other ones" [az ország nyugati határát nehéz észrevenni ezen az ábrán. De annál inkább a többit] (Prinz 1938: 96-97). 
Gyuris, Ferenc. "Human Geography, Cartography, and Statistics: A Toolkit for Geopolitical Goals in Hungary until World War II." Hungarian Cultural Studies. e-Journal of the American Hungarian Educators Association, Volume 7 (2014): http://ahea.pitt.edu DOI: 10.5195/ahea.2014.173

Beyond such attempts to stress the superiority of Hungary in terms of culture and civilization, a work by Prinz and Teleki (1937) explicitly presented Hungary as the link between the center and periphery of Europe, and a torchbearer of European civilization for countries in the east and southeast. The authors depicted here the "rings" of "European civilization and embourgeoisement" (Fig. 10), with Brussels marked as the center. According to Prinz and Teleki: "Brussels is identified as the geometric center of the culture that achieved the highest universal level in progress, the so-called full culture; the boundary line of this area extends along a radius of one thousand kilometers from Brussels" [a haladásban legmagasabb egyetemes fokot elért, úgynevezett teljes kultúra területének geometriai központjaként Brüsszelt állapították meg, ennek a területnek [...] határvonalát pedig Brüsszel ezer kilóméter hosszú sugarának körében] (Prinz and Teleki 1937: 19; emphasis in the original). The authors did not explain exactly how they identified these centers and borders. Yet, in the related chapter, they made references to the advanced level of agriculture, the imprint of human activity on the landscape, literacy, demographic features (for example, birth, death and infant mortality rates), and the development of railway networks (19-44). At this point, the study follows a complex argument. First, it claims that "Hungary receives the insemination of progress definitely through one gate, the western one [since the modern era]" [Magyarország határozottan egy kapun, a nyugatin keresztül kapja [...] [az újkor óta] az elörehaladás megtermékenyitését] (43; emphasis in original). Second, the authors make it clear that "the road of progress has a single line" [ a haladás útjának egyetlen vonala van] (43). This means that the southeastern peripheries of the continent by necessity have to follow the same road of progress the West was proceeding along, and that they can only access progress from one direction, which leads through Hungary. Third, they underscore that the few examples on the periphery of some direct links with Western Europe are insignificant and cannot promote real progress in these areas. As they write: "The western influence (of Western Europe) [...] that is expressed in the cityscapes of a few capital cities (Bucharest, Athens), is nothing more than an insignificant color stain" [Az a nyugati hatás (de l'Europe occidentale) [...] ami néhány föváros (Bukarest, Athén) utcaképeiben jut kifejezésre, csak jelentéktelen festékfolt] (44). To this they add that "the vibrancies of London and Paris also follow a geographical path to the Balkans, one that passes through Hungary" [London és Párizs kisugárzásai is a maguk földrajzi útján, Magyarországon át jutnak a Balkánra] (44). Given the authors' expectation that the country can fulfill its mission only if it keeps its strength and unity, the revision of Hungary's boundaries becomes a European question of civilization.

This reasoning certainly fit the demand of its time. The interwar political discourse in France as well as Britain was strongly influenced by visions of an integrated continent that would secure Europe's future (Heffernan 2007) (these visions ran parallel with colonial discourses that still presented colonization in terms of a civilizing mission). The study by Prinz and Teleki, however, could provide neither a firm justification for how categories of "progress" and "civilization" should be defined, nor a detailed explanation for why progress followed a single line, and why the spots of western influence in Romania or Greece, for example, were just "insignificant color stains." Why, in turn, was Hungary the gatekeeper to progress for nations on the eastern and south-eastern periphery? Though the concepts floated by Prinz and Teleki were formulated in a language that was potentially attractive to "Western" and Hungarian politicians and scientists alike, their justification lacked clarity, and more importantly a legitimate moral and political foundation. 


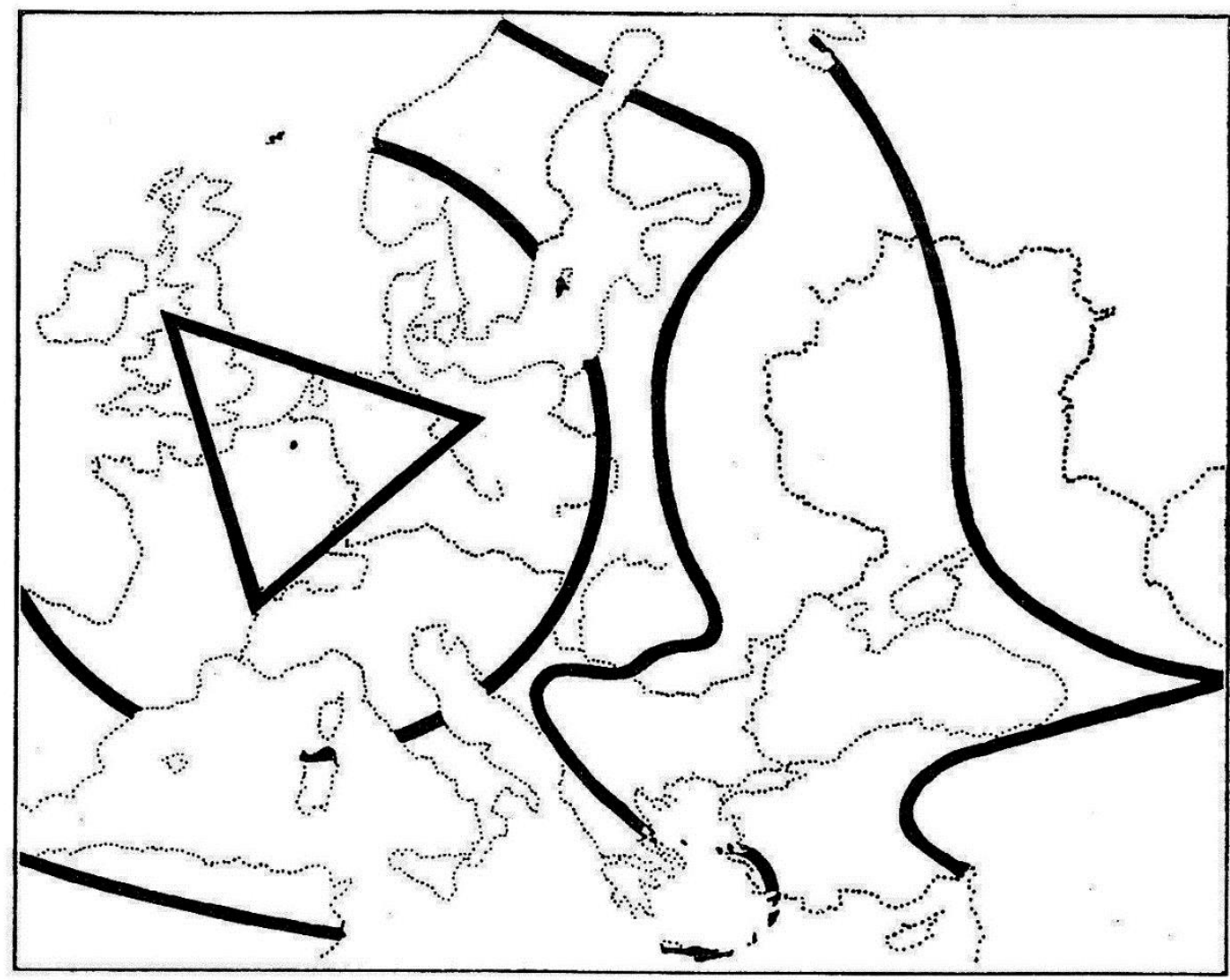

Fig. 10 The rings of "European civilization" and "embourgeoisement." Note the eastward protrusion on the front line of "progress" along Greater Hungary's eastern and southeastern boundaries. Adapted from Prinz and Teleki (1937: 21).

\section{Conclusion}

From the very beginning, geography, just as any other knowledge set, has never functioned in isolation, but rather has evolved within a dynamic social, economic, and political context. As a consequence, it has never been independent from the political power, with its mutual cooperation intensifying remarkably during the age of colonization and the emergence of nation states, only to achieve an unprecedented level during World War I. Beyond generating knowledge that the military needed in order to plan war operations, geography proved even more useful in creating propagandistic knowledge to influence not only the general public, but also the leaders and intelligentsia of allied, neutral, and enemy countries alike. Thematic maps, combining the legitimate authority of science with the power of visual media, turned out to have an especially high value for engineers of the war machine and architects of the new postwar order.

Given the massive territorial claims made by many of its rivals in the European political arena, Hungary was no exception to this. Having functioned as a firm supporter of the country's geopolitical goals since its inception, Hungarian geography as a discipline gained in importance and prestige in the eyes of the postwar political regime. Beginning with the preparations for the peace conference, and then continuing into the entire interwar period, geographers made great efforts to provide arguments for sustaining, and after 1920, reestablishing Greater Hungary. 
Gyuris, Ferenc. "Human Geography, Cartography, and Statistics: A Toolkit for Geopolitical Goals in Hungary until World War II." Hungarian Cultural Studies. e-Journal of the American Hungarian Educators Association, Volume 7 (2014): http://ahea.pitt.edu DOI: 10.5195/ahea.2014.173

These arguments embraced: the geographical unity of the Carpathian Basin in terms of both elevation and drainage systems; the impossibility of rigorously applying the ethnic principle; the economic unity and complexity within the Carpathian Basin; the strategically weak borders; and the resulting political instability in Central Europe. Some geographers also referred to the image of a "harmonious" prewar Hungary in terms of center-periphery relations, or to the historical stability of the old boundaries as proof that Greater Hungary had been founded in accordance with scientific laws. Furthermore, revising the boundaries of postwar Hungary was also presented as a crucial prerequisite for an efficient expansion of European civilization and culture (especially toward the Balkans), and thus was seen as being in the interest of the entire continent.

Thematic maps and statistical figures were used extensively to underscore and popularize these arguments, although their substantiation was problematic at several points. Yet, because they seemed quite convincing, it is not surprising that their main underlying conceptual units (as elements of a geopolitical "toolkit") were to be found in many other countries' official propaganda as well. The fierce rivals of Hungary were no exception. They used many concepts and methods similar to those in Hungary in order to justify profoundly antithetical goals. Isaiah Bowman, the chief expert of geography of the U.S. delegation at the peace conference, grasped this phenomenon in his memoirs: "Each one of the Central European nationalities had its own bagful of statistical and cartographical tricks. When statistics failed, use was made of maps in color. It would take a huge monograph to contain an analysis of all the types of map forgeries that the war and the peace conference called forth. A new instrument was discovered-the map language. A map was as good as a brilliant poster, and just being a map made it respectable, authentic. A perverted map was a life belt to many a foundering argument." (Bowman 1921: 142; cited in Palsky 2002: 113). We can add that Bowman's words could have referred not only to World War I and the peace negotiations, but to the entire interwar period.

In light of this article one can reasonably raise the question about the motivations of the geographers who produced the material presented above. My point is that present day researchers can and must learn from the past of their discipline. It is also important, however, to avoid coming to simplistic conclusions about "unscrupulous" scientists or "guilty" disciplines (on how this played out in the communist period see Györi and Gyuris 2012: 114). Rather, geopolitical rivalry and later the war itself gradually militarized every sphere of life, including science and personal views. On all sides we see scientists devoted to their discipline, loyal to their homelands, and maybe loving some other nations as well, but who also hold to a firm belief that their work can contribute to a just world. Scientists who found themselves in situations where they considered adopting geographical science to geopolitical interests their personal responsibility, and maybe saw this the only opportunity they had to represent the most fundamental values they believed in. In my view, a possible and valid moral conclusion about the findings presented in this article is thus that the entire society, but perhaps especially politicians and the intelligentsia (including geographers), have a responsibility to do their best under peaceful circumstances to avoid situations which, if they emerge, will most likely or even unavoidably lead to the militarization of the mind. The goal, in the end, is not try to win wars, but to avoid them. 
Gyuris, Ferenc. "Human Geography, Cartography, and Statistics: A Toolkit for Geopolitical Goals in Hungary until World War II." Hungarian Cultural Studies. e-Journal of the American Hungarian Educators Association, Volume 7 (2014): http://ahea.pitt.edu DOI: 10.5195/ahea.2014.173

\section{Works Cited}

Boulineau, Emmanuelle. 2001. "Un géographe traceur de frontiers: Emmanuel de Martonne et la Roumanie ['A Geographer Plotting Borders: Emmanuel de Martonne and Romania']." L'Espace géographique ['The Geographical Space'] 30.4 (2001): 358-369.

Bowd, Gavin. 2011. "Emmanuel de Martonne et la naissance de la Grande Roumanie ['Emmanuel de Martonne and The Birth of Great Romania']." Revue Roumaine de Géographie ['Romanian Journal of Geography'] 55.2 (2011): 103-120.

Bowman, Isaiah. 1921. "Constantinople and the Balkans," in What Really Happened at Paris: The Story of the Peace Conference, 1918-1919 by American Delegates, eds. Edward Mandell House and Charles Seymour. New York: Charles Scribner's Sons. 140-175.

Cholnoky, Jenö. 1937. A Föld és élete VI. Magyarország földrajza ['The Earth and Its Life 6. The Geography of Hungary']. Budapest: Franklin-Társulat [Franklin Society].

Dövényi, Zoltán. 2008. "Rónai András: vázlatos pályakép [András Rónai: Sketch of a LifeWork].” Földrajzi Értesitő ['Geographical Bulletin'] 62.1-2 (2008): 9-20.

de Martonne, Emmanuel. 1921. La Roumanie Nouvelle ['The New Romania']. Paris: Léon Eyrolles.

Fodor, Ferenc. 1925. "A statisztikai értékelés a gazdasági földrajzban” ['Statistical Evaluation in Economic Geography']. Földrajzi Közlemények ['Geographical Review'] 53.9-10 (1925): 202-210.

—. 2006. A magyar földrajztudomány története ['The History of Hungarian Geography']. Budapest: Geographical Research Institute, Hungarian Academy of Sciences.

Godlewska, Anne and Jason Grek Martin. 2009. "Map," in The SAGE Handbook of Geographical Knowledge. Eds. John A. Agnew and David N. Livingstone. London, Thousand Oaks, CA, New Delhi, Singapore: SAGE: 357-367.

Győri, Róbert. 2001. “A magyar gazdaságföldrajz a két világháború között ['Hungarian Economic Geography Between the World Wars']," in Geográfia az ezredfordulón. Regionális Tudományi Tanulmányok 6. ['Geography At The Turn of the Millenium. Studies in Regional Science 6.’]. Ed. József Nemes Nagy. Budapest: Eötvös Loránd University, Department of Regional Geography: 61-83.

. 2007. "Dunántúl - valóság vagy fikció? A történeti földrajz bizonyítékai ['Transdanubia - Reality of Fiction? Some Proofs from Historical Geography'].” Limes 20.3 (2007): 722.

. 2011. “A múlttal való tudományos leszámolás - Eötvös collegista geográfusok az 1950es években ['Scientific Reckoning with the Past - Geographers in Eötvös Collegium in the 1950s']," in Lustrum. Solemnia aedificii a.D. MCMXI inaugurati ['Ceremony. Formalities of the Building Inaugurated in AD 1911']. Eds. László Horváth, Krisztina Laczkó, Károly Tóth and András Péterffy. Budapest: Typotex-Eötvös Collegium: 288311.

Győri, Róbert and Ferenc Gyuris. 2012. "The Sovietisation of Hungarian Geography, 19451960." Mitteilungen der Österreichischen Geographischen Gesellschaft ['Review of the Austrian Geographical Society]' 154 (2012): 107-128.

Gyuris, Ferenc. 2009. “A Teleki-iskola módszertani újításai a két világháború közötti magyar társadalomföldrajzban ['Methodical innovations of the Teleki school in interwar Hungarian human geography']," in Tudós tanárok az Eötvös Collegiumban [Scientist 
Gyuris, Ferenc. "Human Geography, Cartography, and Statistics: A Toolkit for Geopolitical Goals in Hungary until World War II." Hungarian Cultural Studies. e-Journal of the American Hungarian Educators Association, Volume 7 (2014): http://ahea.pitt.edu DOI: 10.5195/ahea.2014.173

teachers in Eötvös Collegium], eds. Enikő Sepsi and Károly Tóth. Budapest: Ráció. 138164.

Hajdú, Zoltán. 1987. "Vonzáskörzetkutatás a felszabadulás előtti magyar földrajztudományban ['Catchment Area Research in Hungarian Geography Before the Liberation']." Tér és Társadalom ['Space and Society'] 1.1 (1987): 87-95. . 1998. Changes in the Politico-Geographical Position of Hungary in the $20^{\text {th }}$ Century. (Discussion Papers No. 22.) Pécs: Centre for Regional Studies, Hungarian Academy of Sciences.

—. 2000. “A magyar földrajztudomány és a trianoni békeszerződés. 1918-1920 ['Hungarian Geography and the Trianon Peace Treaty'].” Kisebbségkutatás ['Minority Research'] 9.1 (2000): 224-233.

. 2007. “A magyarországi Délkelet-Európa (Balkán) kutatások hagyományai, fontossága ['Traditions and Importance of Southeast Europe (Balkan) Studies in Hungary']," in Délkelet-Európa: államhatárok, határon átnyúló kapcsolatok, térstruktúrák ['Southeast Europe: National Boundaries, Cross-border Connections, Spatial Structures’]. Eds. Zoltán Hajdú, Iván Illés and Zoltán Raffay. Pécs: Centre for Regional Studies, Hungarian Academy of Sciences: 13-46.

Heffernan, Michael. 1996. "Geography, Cartography and Military Intelligence: The Royal Geographical Society and the First World War," Transactions of the Institute of British Geographers 21.3 (1996): 504-533.

- 2000. "Mars and Minerva: Centres of Geographical Calculation in an Age of Total War," Erdkunde 54.4 (2000): 320-333.

- 2001. "History, Geography, and the French National Space: The Question of AlsaceLorraine, 1914-18," Space \& Polity 5.1 (2001): 27-48. . 2002. "The Politics of the Map in the Early Twentieth Century," Cartography and Geographic Information Services 29.3 (2002): 207-226.

- 2007. "European Dreaming: France, Britain and The New Europe, c. 1914 - c. 1945," in The European Geographical Imagination (Hettner-Lectures 10.), ed. Michael Heffernan. Heidelberg: University of Heidelberg, Department of Geography. 41-60. . 2009. "Histories of Geography," in Key Concepts in Geography ( $2^{\text {nd }}$ edn. ), eds. Nicholas Clifford, Sarah Holloway, Stephen P. Rice, Gill Valentine. London, Thousand Oaks, CA, New Delhi, Singapore: SAGE. 3-20.

Hunfalvy, János. 1863. A Magyar Birodalom természeti viszonyainak leírása. 1. kötet ['Description of the natural conditions of the Hungarian Empire. Vol. 1']. Pest: Emich Gusztáv.

Jobbitt, Steven. 2011. "Playing the Part: Hungarian Boy Scouts and the Performance of Trauma in Interwar Hungary," AHEA: E-Journal of the American Hungarian Educators Association 4 (2011): 1-15.

Keményfi, Róbert. 2006. "Egységes magyar államtér alatt egységes kőzetalap: A Tisiamasszívum mítosza ['Unitary Lithological Base Beneath Unitary Hungarian National Space: The Myth of Tisia Massive']," in Kárpát-medence: települések, tájak, régiók, térstruktúrák ['Carpathian Basin: Settlements, Landscapes, Regions, Spatial Structures']. Eds. Róbert Győri and Zoltán Hajdú. Budapest, Pécs: Dialóg Campus: 418-438. . 2008. “»Kulturális hatóerönk« mitikus történeti földrajzi háttere” ['The Mythical Background of Hungary's Cultural Power in Historical Geography']. Korall 31 (2008): 101-131. 
Gyuris, Ferenc. "Human Geography, Cartography, and Statistics: A Toolkit for Geopolitical Goals in Hungary until World War II." Hungarian Cultural Studies. e-Journal of the American Hungarian Educators Association, Volume 7 (2014): http://ahea.pitt.edu DOI: 10.5195/ahea.2014.173

Klebelsberg, Kuno. 1927. "Beköszöntőbeszéd ['Inaugural Speech']," in Gróf Klebelsberg Kuno beszédei, cikkei és törvényjavaslatai 1916-1926 ['Speeches, Articles and Bills of Count Kuno Klebelsberg 1916-1926’]. Eds. Kuno Klebelsberg. Budapest: Athenaeum: 604-608. Klinghammer, István. 2008. "Rónai András: Közép-Európa atlasz - egy térképmü mesterfokon" ['András Rónai: Atlas of Central Europe - A Masterpiece of Cartography']. Földrajzi Értesítö ['Geographical Bulletin'] 57.1-2 (2008): 71-75.

Kocsis, Károly. 2008. "Rónai András, az etnikai földrajzos” ['András Rónai, the Ethnic Geographer']. Földrajzi Értesítő ['Geographical Bulletin'] 62.1-2 (2008): 55-70.

Konrád, George [György] and Ivan [Iván] Szelényi. 1979. The Intellectuals on the Road to Class Power: A Sociological Study of the Role of the Intelligentsia in Socialism. New York: Harcourt, Brace, Jovanovich.

Kőszegi, Margit. 2011. A rendszerváltás utáni évtized társadalmi folyamatainak etnikai földrajzi vizsgálata Bulgáriában ['An ethnic geographic analysis of social processes in Bulgaria in the first decade after transition']. PhD thesis. Budapest: Eötvös Loránd University, Institute of Geography and Earth Sciences.

Krasznai, Zoltán. 2003. "Szakértelem és geopolitika. Földrajztudósok az első világháború után: Emmanuel de Martonne és Teleki Pál ['Expertise and Geopolitics. Geographers after World War I: Emmanuel de Martonne and Pál Teleki'],’ in Léptékváltó társadalomtörténet. (Tanulmányok a 60 éves Benda Gyula tiszteletére.) ['Scale-shifting Social History (Essays in Honour of Gyula Benda at His Sixtieth Birthday)']. Eds. Zsolt K. Horváth, András Lugosi, Ferenc Sohajda Zsolt. Budapest: Hermész Kör, Osiris: 345365.

—. 2012. Földrajztudomány, oktatás és propaganda. A nemzeti terület reprezentációja a két világháború közötti Magyarországon ['Geography, Education, and Propaganda: The Representation of National Territory in Interwar Hungary’]. Pécs: Publikon.

Livingstone, David N. 2002. "Tropical Hermeneutics and the Climatic Imagination," in Science, Space, and Hermeneutics (Hettner-Lectures 5.). Ed. David N. Livingstone. Heidelberg: Department of Geography, University of Heidelberg. 43-73.

- 2009. "Science/Science Studies," in The Dictionary of Human Geography (5 ${ }^{\text {th }}$ edn.). Eds. Derek Gregory, Ron Johnston, Geraldine Pratt, Michael Watts and Sarah Whatmore. Chichester: Wiley: 666-668.

—. 2011. "Environmental Determinism," in The SAGE Handbook of Geographical Knowledge. Eds. John A. Agnew and David N. Livingstone. London, Thousand Oaks, CA, New Delhi, Singapore: SAGE: 368-380.

Magyar Földrajzi Társaság ['Hungarian Geographical Society']. 1918. “A Magyar Földrajzi Társaság szózata a világ Földrajzi Társaságaihoz" ['Manifesto of the Hungarian Geographical Society to Geographical Societies of the World']. Földrajzi Közlemények ['Geographical Review'] 46.7-10 (1918): 289-320.

Meusburger, Peter. 2005. "Sachwissen und Orientierungswissen als Machtinstrument und Konfliktfeld. Zur Bedeutung von Worten, Bildern und Orten bei der Manipulation des Wissens" ['Factual and Symbolic Knowledge as Instruments of Power and Fields of Conflict. On the Significance of Words, Images and Places in the Manipulation of Knowledge']. Geographische Zeitschrift ['Geographical Journal'] 93.3 (2005): 148-164. Meusburger, Peter, Michael Heffernan and Edgar Wunder. 2011. "Cultural Memories: An Introduction," in Cultural Memories: The Geographical Point of View (Knowledge and 
Space vol. 4). Eds. Peter Meusburger, Michael Heffernan and Edgar Wunder. Dordrecht: Springer: 3-14.

Palsky, Gilles. 2002. "Emmanuel de Martonne and the Ethnographical Cartography of Central Europe (1917-1920)". Imago Mundi ['Image of the World'] 54.1 (2002): 111-119.

Parry, John Horace. 1982. The Age of Reconnaissance: Discovery, Exploration and Settlement 1450 to 1650. Berkeley, Los Angeles, London: University of California Press.

Prinz, Gyula. 1926. Magyarország földrajza ['The Geography of Hungary']. Budapest: Danubia. . 1936. Magyar föld, magyar faj 1. Magyar földrajz: Magyarország tájrajza ['Hungarian Land, Hungarian Race 1. Hungarian Geography: The Regional Geography of Hungary']. Budapest: Királyi Magyar Egyetemi Nyomda ['Royal Hungarian University Press']. . 1938. Magyar föld, magyar faj 3. Magyar földrajz: Az államföldrajzi kép ['Hungarian Land, Hungarian Race 3. Hungarian Geography: The Image of Political Geography']. Budapest: Királyi Magyar Egyetemi Nyomda ['Royal Hungarian University Press'].

Prinz, Gyula and Pál Teleki. 1937. Magyar föld, magyar faj 2. Magyar földrajz: A magyar munka földrajza ['Hungarian Land, Hungarian Race 2. Hungarian Geography: The Geography of Hungarian Labor']. Budapest: Királyi Magyar Egyetemi Nyomda ['Royal Hungarian University Press'].

Richards, Thomas. 1993. The Imperial Archive: Knowledge and the Fantasy of Empire. London: Verso.

Rónai, András. 1936. "Egy harmonikus államterület statisztikai képe ['Statistical Image of a Harmonious National Territory'].” Földrajzi Közlemények ['Geographical Review']. 64.1-5 (1936): 9-28.

—. 1945. Középeurópa atlasz ['Atlas of Central Europe']. Balatonfüred and Budapest: Államtudományi Intézet ['Institute of Political Sciences'].

Romsics, Ignác. 2007. A trianoni békeszerzödés ['The Trianon Peace Treaty']. Budapest: Osiris.

- 2010. Magyarország története a XX. században ['The History of Hungary in the Twentieth Century']. Budapest: Osiris.

Teleki, Pál. 1922. "Statisztika és térkép a gazdasági földrajzban” ['Statistics and Map in Economic Geography']. Földrajzi Közlemények ['Geographical Review']. 50.1-5 (1922): 74-91. . 1937. "Egy néprajzi térképröl” ['About an Ethnographic Map']. Földrajzi Közlemények ['Geographical Review']. 65.4-5. (1937): 60-70.

van der Velde, Paul. 1995. "The Royal Dutch Geographical Society and the Dutch East Indies, 1873-1914: From Colonial Lobby to Colonial Hobby,” in Geography and Imperialism 1820-1940. Eds. Morag Bell, Robin Butlin and Michael Heffernan. Manchester: Manchester University Press: 80-92. 